OPEN ACCESS

Edited by:

Victor Kuete,

University of Dschang, Cameroon

Reviewed by:

Kannan R. R. Rengasamy,

Department of Biotechnology,

Alagappa University, India

Pinarosa Avato,

Università degli Studi di Bari Aldo

Moro, Italy

*Correspondence:

Khairana Husain

khairana@ukm.edu.my

Specialty section:

This article was submitted to

Ethnopharmacology,

a section of the journal

Frontiers in Pharmacology

Received: 27 November 2017

Accepted: 31 January 2018

Published: 16 February 2018

Citation:

Abd Rani NZ, Husain K and Kumolosasi E (2018) Moringa Genus: A Review of Phytochemistry and Pharmacology.

Front. Pharmacol. 9:108. doi: 10.3389/fphar.2018.00108

\section{Moringa Genus: A Review of Phytochemistry and Pharmacology}

\author{
Nur Zahirah Abd Rani, Khairana Husain* and Endang Kumolosasi \\ Drug and Herbal Research Centre, Faculty of Pharmacy, Universiti Kebangsaan Malaysia, Kuala Lumpur, Malaysia
}

Moringa is a genus of medicinal plants that has been used traditionally to cure wounds and various diseases such as colds and diabetes. In addition, the genus is also consumed as a source of nutrients and widely used for purifying water. The genus consists of 13 species that have been widely cultivated throughout Asia and Africa for their multiple uses. The purpose of this review is to provide updated and categorized information on the traditional uses, phytochemistry, biological activities, and toxicological research of Moringa species in order to explore their therapeutic potential and evaluate future research opportunities. The literature reviewed for this paper was obtained from PubMed, ScienceDirect, and Google Scholar journal papers published from 1983 to March 2017. Moringa species are well-known for their antioxidant, anti-inflammatory, anticancer, and antihyperglycemic activities. Most of their biological activity is caused by their high content of flavonoids, glucosides, and glucosinolates. By documenting the traditional uses and biological activities of Moringa species, we hope to support new research on these plants, especially on those species whose biological properties have not been studied to date.

Keywords: Moringaceae, Moringa, glucosinolates, pharmacological activity, phytochemistry

\section{INTRODUCTION}

The genus Moringa is one of the genera found in the Moringaceae family along with Anoma and Hyperanthera. It is well-known as the "drumstick" or "horseradish" family. The Moringa genus comprises 13 species distributed through southwest Asia, southwest Africa, northeast Africa, and Madagascar. The species and their distributions are listed in Table 1.

Among the 13 species, current research is limited to Moringa oleifera, Moringa stenopetala, Moringa concanensis, and Moringa peregrina. As the other species are endemic to Madagascar and Northeast Africa, they are being evaluated less as there is less exploration for naturally occurring bioactive substances in these locations. In contrast, M. oleifera, which is native to India, is being studied widely. As a result, the species has been cultivated throughout the world, specifically in Asia, Latin America, Florida, the Caribbean, and the Pacific Islands (Fahey, 2005).

The species in this genus can be categorized into three groups depending on their type of trunk (Olson and Rosell, 2006). M. stenopetala, Moringa drouhardii, Moringa ovalifolia, and Moringa hildebrandtii have bloated water-storing trunks and are known as bottle trees. Meanwhile, $M$. peregrina, M. concanensis, and $M$. oleifera have slender trunks. The remaining species are tuberous shrubs endemic to Northeast Africa. Moringa species are also resistant to drought, and can grow fast without needing much care.

The Moringa genus has traditionally been widely used to improve health. Kings and queens used Moringa to improve their alertness and to maintain healthy skin. Indian warriors were fed 
TABLE 1 | List of Moringa species throughout the world.

\begin{tabular}{|c|c|c|}
\hline Species & Country & Trivial name \\
\hline M. arborea Verdcourt & Kenya, Somalia & - \\
\hline M. borziana Mattei & Kenya, Somalia & - \\
\hline M. concanensis Nimmo & India & - \\
\hline M. drouhardii Jumelle & Southern Madagascar & - \\
\hline M. hildebrandtii Engler & $\begin{array}{l}\text { Southwest } \\
\text { Madagascar }\end{array}$ & Hildebrandt's Moringa \\
\hline M. longituba Engler & $\begin{array}{l}\text { Kenya, Southeast } \\
\text { Ethiopia, Somalia }\end{array}$ & Moringa tubiflora \\
\hline M. oleifera Lam. & India & $\begin{array}{l}\text { Horseradish, Ben-oil } \\
\text { Drumstick, Kelor }\end{array}$ \\
\hline $\begin{array}{l}\text { M. ovalifolia Dinter ex } \\
\text { Berger }\end{array}$ & $\begin{array}{l}\text { Namibia, Southwest } \\
\text { Angola }\end{array}$ & $\begin{array}{l}\text { Phantom Tree, Ghost } \\
\text { Tree, African Moringo }\end{array}$ \\
\hline $\begin{array}{l}\text { M. peregrina Forssk. } \\
\text { Ex Fiori }\end{array}$ & $\begin{array}{l}\text { Red Sea, Arabia, } \\
\text { Northeast Africa }\end{array}$ & $\begin{array}{l}\text { Ben tree, } \\
\text { wispy-needled Yasar } \\
\text { tree, Wild drumstick } \\
\text { tree, Yusor, Al Yassar, } \\
\text { Al Ban }\end{array}$ \\
\hline M. pygmaea Verdcourt & North Somalia & \\
\hline M. rivae Chiovenda & Kenya, Ethiopia & Swanjehro \\
\hline M. ruspoliana Engler & $\begin{array}{l}\text { Kenya, Ethiopia, } \\
\text { Somalia }\end{array}$ & \\
\hline $\begin{array}{l}\text { M. stenopetala (Baker } \\
\text { f.) Cufodontis }\end{array}$ & $\begin{array}{l}\text { Kenya, Southwest } \\
\text { Ethiopia, Somalia }\end{array}$ & $\begin{array}{l}\text { Cabbage tree, Haleko, } \\
\text { Shelagda, Shiferaw }\end{array}$ \\
\hline
\end{tabular}

All listed species were validated taxonomically from The Plant List (www.theplantlist.org, V1.1, 2013), Bihrmann's Caudiciforms (www.bihrmann.com).

M. oleifera leaves to enhance their energy and help to relieve their pain and stress during war (Mahmood et al., 2010). Other traditional uses of the genus are in healing skin infections, anxiety, asthma, wounds, fever, diarrhea, and sore throats.

The genus is well-known for its multiple uses. The seeds are used for purifying water, the leaves as nutrition supplements, the oil as a biofuel, the trunks as gum, the flowers as honey, and all of the plant parts can also be used for medicinal purposes (Fahey, 2005). M. oleifera, which is also known as the "Miracle Tree" and "Mother's Best Friend," has been named the most nutrientrich plant. Other than having a high concentration of vitamin $\mathrm{A}$, vitamin $\mathrm{C}$, potassium, and calcium, the plant contains all the essential amino acids (Mahmood et al., 2010).

Various research has been conducted on this genus to study its biological properties, especially on $M$. oleifera that has been under study since the 1970s (Mahmood et al., 2010). Currently, it is well-known that the plant has anti-inflammatory, antioxidant, anticancer, and antidiabetic activities. Recently, more research has been conducted on other species such as $M$. concanensis, $M$. stenopetala, and M. peregrina. However, no profound research on other species has been found. This review will primarily compile all the traditional uses, phytochemical contents, and biological activities of the Moringa genus, aiming to encourage new research on other species.

\section{TRADITIONAL USES}

All the different parts of Moringa plants have been reported to have medicinal values. The traditional medicinal uses of
Moringa species are tabulated in Table 2. Other than the species listed in Table 2, Moringa arborea, Moringa longituba, Moringa borziana, Moringa pygmaea, and M. hildebrandtii have also been reported to have medicinal value but have not been mentioned in connection with any specific activity. Moringa species are highly nutritious which benefits people in terms of providing daily nutritional supplements and boosting their immune systems (Popoola and Obembe, 2013). Mahmood et al. (2010) reported that Moringa leaves contain vitamin $\mathrm{C}$, vitamin A, and high concentrations of essential amino acids. In addition, because the species are resistant to drought, Moringa species become valuable during the dry season when other vegetables are not available. In fact, M. stenopetala can be found in all households in the Gamo Gofa zone (Seifu, 2014). Mathur (2005) stated in his book that Moringa leaves are highly nutritious, with two times more protein than yogurt, four times more vitamin A than carrots, three times more potassium than bananas, seven times more vitamin $\mathrm{C}$ than oranges, and four times more calcium than milk. Zaghloul et al. (2012) reported that $M$. peregrina was also used as fodder to increase animal weight while $M$. oleifera contains high amount of zeatin that has been used as a natural plant growth enhancer and helps to increase crop yields (Leone et al., 2015b).

As well as their medicinal uses, $M$. drouhardii, M. longituba, M. peregrina, M. stenopetala, and $M$. oleifera have been used as coagulants to help clarifying water in addition to having antimicrobial activity (Bazrafshan et al., 2012; Dalvand et al., 2016). The high oleic acid content and high stability of $M$. ovalifolia, $M$. stenopetala, and $M$. oleifera seed oil makes it suitable to use as edible oil, cosmetic oil, biodiesel, and lubrication oil for machinery and watches (Rashid et al., 2008). Other than that, M. stenopetala is also used to expel snakes (Seifu, 2014), while the unique stature of $M$. hildebrandtii with its large trunk, and leaves and its scented flowers, is used to mark special occasions. It is also planted around the graves of the Mahabo tribe (Olson and Razafimmandimbison, 2000).

\section{PHYTOCHEMISTRY}

Moringa species contain various phytoconstituents such as alkaloids, saponins, tannins, steroids, phenolic acids, glucosinolates, flavonoids, and terpenes. The diversity of these phytochemicals in the genus contributes to its numerous pharmacological uses. About 110 compounds were identified from the genus and are tabulated in Figure 1 and Table 3. Some of these compounds showed positive results when tested for various biological activities. In addition to these 110 compounds, the genus contains more compounds as detected by GC-MS. Regardless of the high phytochemical contents of the genus, the constituents of only specific species had been explored, namely $M$. concanensis, $M$. peregrina, $M$. stenopetala, and $M$. oleifera, and most of the studies focused on the leaves of the plants.

\section{Flavonoids}

The Moringa genus has high antioxidant activity mainly due to its high content of flavonoids. Most of the flavonoids present in the genus are in the flavanol and glycoside form. The most 
TABLE 2 | Ethnomedicine of Moringa species.

\begin{tabular}{|c|c|c|c|}
\hline Species & Part & Traditional uses & References \\
\hline \multirow[t]{3}{*}{ M. concanensis } & Bark & Reduce pain, abortifacient & Patil and Patil, 2005 \\
\hline & Leaves & External tumors & Chitravadivu et al., 2009 \\
\hline & Resin & Fire burn wounds & \\
\hline M. drouhardii & Bark & Colds and coughs & Olson, 1999 \\
\hline \multirow[t]{2}{*}{ M. peregrina } & Leaves & Skin rashes, paralysis & Odee et al., 2002 \\
\hline & Leaves, roots & $\begin{array}{l}\text { Malaria, hypertension, stomach disorder, expel retained } \\
\text { placenta, asthma, diabetes }\end{array}$ & Mekonnen et al., 1999 \\
\hline \multirow[t]{2}{*}{ M. rivae } & Leaves & Weakness of thigh and calf muscles & Forest Department, 2016 \\
\hline & Gum & Arthritis & \\
\hline M. ruspoliana & - & $\begin{array}{l}\text { Eye and throat infections, tsetse fly bites, livestock } \\
\text { diseases, abdominal pains, sexually transmitted diseases }\end{array}$ & Odee et al., 2002 \\
\hline \multirow{3}{*}{ M. stenopetala } & Leaves & $\begin{array}{l}\text { Malaria, hypertension, expel retained placenta, stomach } \\
\text { pain, visceral leishmanial, diabetes, wound healing, } \\
\text { common cold }\end{array}$ & \\
\hline & Bark & Cough & Teklehaymanot and Giday, 2010 \\
\hline & Root & Epilepsy, help during labor & \\
\hline \multirow[t]{5}{*}{ M. oleifera } & Leaf & $\begin{array}{l}\text { Diarrheal, dysentery, colitis, sores, skin infection, anemia, } \\
\text { cuts, scrapes, rashes, sign of aging }\end{array}$ & Silver, 2017 \\
\hline & Gum & Fevers, dysentery, asthma, dental decay & \\
\hline & Seeds & Warts & \\
\hline & Leaves & Antibacterial, antimalarial & Parrotta, 1993 \\
\hline & Oil & Gout, acute rheumatism & \\
\hline
\end{tabular}

common flavonoids of the genus are rutin (1), quercetin (3), rhamnetin (6), kaempferol (8), apigenin (9), and myricetin (14). Optimization research has been conducted to discover the best way to extract flavonoids from $M$. oleifera with highest yield. As a result, subcritical ethanol extraction yielded $26.7 \%$ more flavonoid than a reflux method (Wang et al., 2017).

\section{Glucosinolate}

Moringa species contain abundant glucosinolates. The most abundant glucosinolate present in the species is $4-O-(\alpha-$ $L$-rhamnopyranosyloxy)-benzyl glucosinolate (30), also known as glucomoringin (GMG). Three isomers of 4-O( $\alpha$ - $L$-acetylrhamnopyrosyloxy)-benzyl glucosinolate (31-33) were also detected in $M$. oleifera leaves, depending on the maturity and physiological properties of the leaves (Leone et al., 2015b).

Disruption of plant tissues usually from cutting or chewing caused the release of myrosinase which, when in contact with glucosinolates produces isothiocyanates. The most abundant isothiocyanate found in the genus, 4 -[( $\alpha$ - $L$-rhamnosyloxy $)$ benzyl] isothiocyanate (GMG-ITC) (34), is derived from 4-O( $\alpha$-L-rhamnopyranosyloxy)-benzyl glucosinolate (30). Recently, isothiocyanates have become a major research interest of Moringa for their various biological activities such as their anticancer, antidiabetic, antimicrobial, and anti-inflammatory effect (Park et al., 2011; Padla et al., 2012; Waterman et al., 2014, 2015). The alkylation of isothiocyanates with proteins and DNA contribute to their biological activity (Nibret and Wink, 2010). 


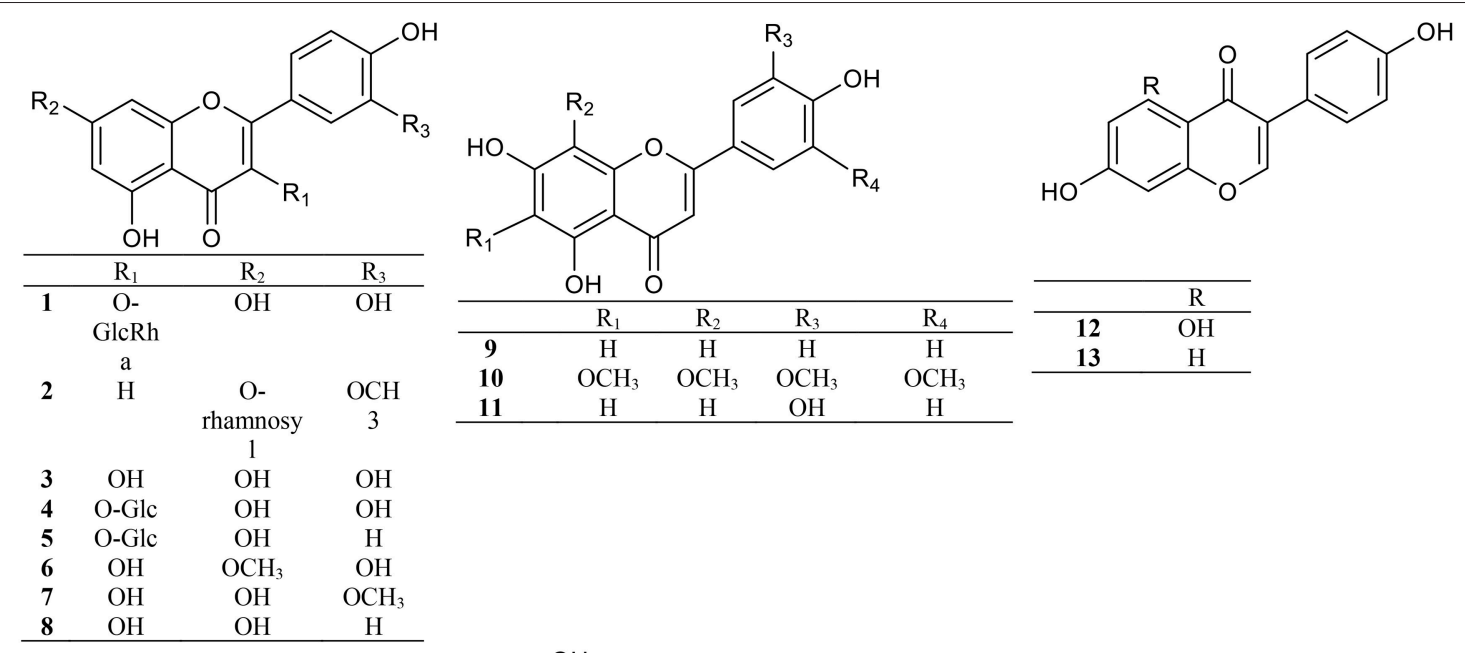<smiles>O=c1c(O)c(-c2cc(O)c(O)c(O)c2)oc2cc(O)cc(O)c12</smiles><smiles>Oc1cc(O)c2c(c1)OC(c1ccc(O)c(O)c1)C(O)C2</smiles>

(15)

(14)<smiles>Oc1cc(O)c2c(c1)OC(OC1Cc3c(O)cc(O)cc3C(O)C1O)(c1ccc(O)c(O)c1)C(c1ccc(O)c(O)c1)O2</smiles><smiles>O=c1cc(-c2ccc(O)cc2)oc2c([C@H]3O[C@H](CO)[C@@H](O)[C@H](O)[C@H]3O)c(O)c([C@@H]3O[C@H](CO)[C@@H](O)[C@H](O)[C@H]3O)c(O)c12</smiles>

(16)

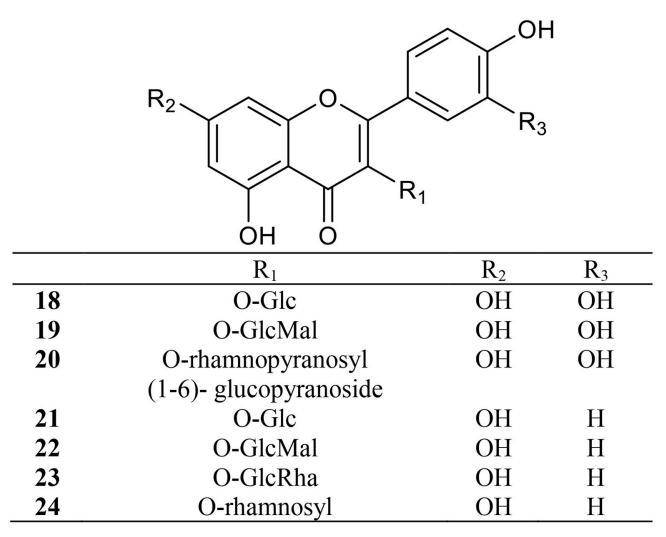

(17)

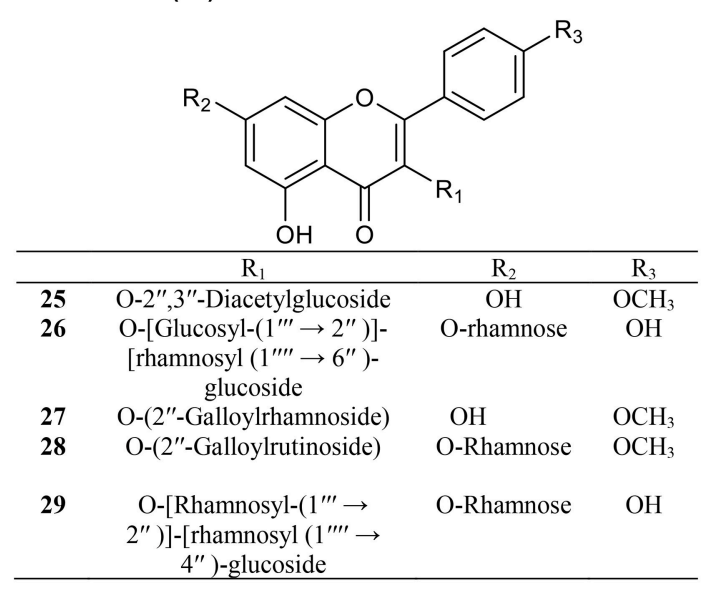




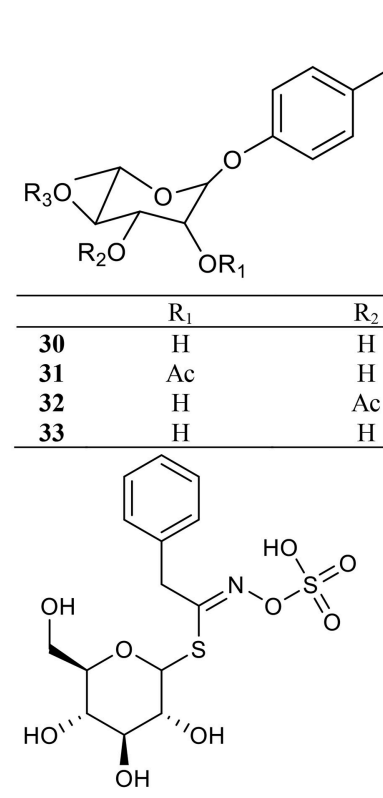

(38)<smiles>CC(C)CSC#N</smiles>

(41)<smiles>CC(C)(O)C/C(=N\OS(=O)(=O)O)S[C@@H]1O[C@H](CO)[C@@H](O)[C@H](O)[C@H]1O</smiles>

(39)

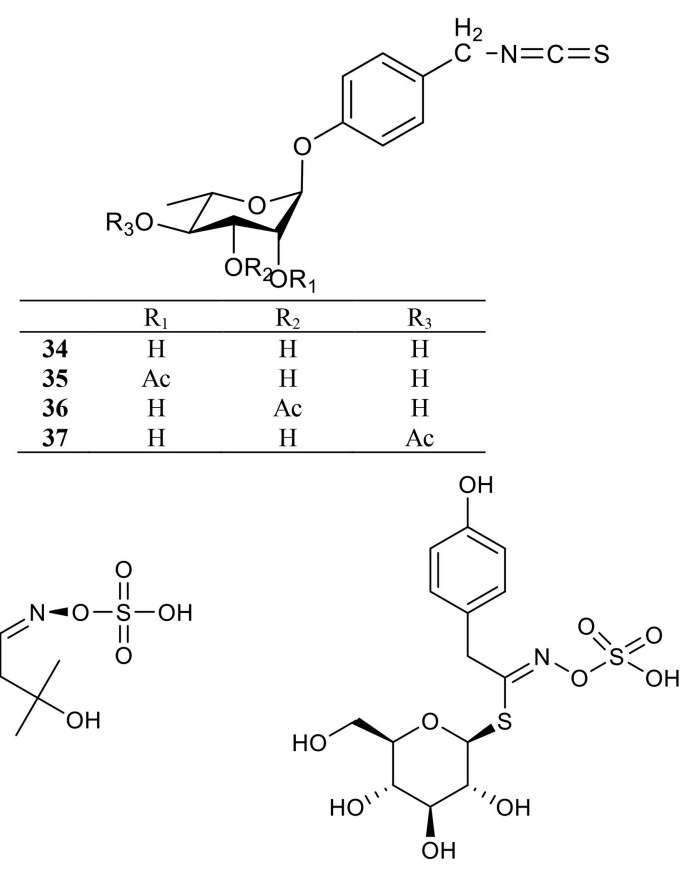

(40)<smiles>CC1C(Oc2ccc(CN=C=S)cc2)C(O)C2OC(O)C(O)C(CO)C(O)OC1C2O</smiles>

(43)<smiles>[R]Cc1c([R3])c([R8])c(C(=O)O)c([R8])c1[2H]</smiles><smiles>S=C=NCc1ccccc1</smiles>

(42)<smiles>[R]c1cc(/C=C/C(=O)O)c([R])c([R])c1[R]</smiles>

\begin{tabular}{cccccc}
\hline & $\mathrm{R}_{1}$ & $\mathrm{R}_{2}$ & $\mathrm{R}_{3}$ & $\mathrm{R}_{4}$ & $\mathrm{R}_{5}$ \\
\hline $\mathbf{4 4}$ & $\mathrm{H}$ & $\mathrm{OH}$ & $\mathrm{OH}$ & $\mathrm{OH}$ & $\mathrm{H}$ \\
$\mathbf{4 5}$ & $\mathrm{H}$ & $\mathrm{H}$ & $\mathrm{H}$ & $\mathrm{H}$ & $\mathrm{OH}$ \\
$\mathbf{4 6}$ & $\mathrm{OH}$ & $\mathrm{H}$ & $\mathrm{H}$ & $\mathrm{OH}$ & $\mathrm{H}$ \\
$\mathbf{4 7}$ & $\mathrm{H}$ & $\mathrm{OCH}_{3}$ & $\mathrm{OH}$ & $\mathrm{OCH}_{3}$ & $\mathrm{H}$ \\
\hline
\end{tabular}

\begin{tabular}{ccccc}
\hline & $\mathrm{R}_{1}$ & $\mathrm{R}_{2}$ & $\mathrm{R}_{3}$ & $\mathrm{R}_{4}$ \\
\hline $\mathbf{4 9}$ & $\mathrm{H}$ & $\mathrm{OCH}_{3}$ & $\mathrm{OH}$ & $\mathrm{H}$ \\
$\mathbf{5 0}$ & $\mathrm{H}$ & $\mathrm{OH}$ & $\mathrm{OH}$ & $\mathrm{H}$ \\
$\mathbf{5 1}$ & $\mathrm{OH}$ & $\mathrm{H}$ & $\mathrm{H}$ & $\mathrm{H}$ \\
$\mathbf{5 2}$ & $\mathrm{H}$ & $\mathrm{H}$ & $\mathrm{OH}$ & $\mathrm{H}$ \\
$\mathbf{5 3}$ & $\mathrm{H}$ & $\mathrm{OCH}_{3}$ & $\mathrm{OH}$ & $\mathrm{OCH}_{3}$ \\
\hline
\end{tabular}<smiles>O=c1oc2c(O)c(O)cc3c(=O)oc4c(O)c(O)cc1c4c23</smiles>

(48)<smiles>O=C(/C=C/c1ccc(O)c(O)c1)O[C@@H]1CC[C@@](O)(C(=O)O)C[C@H]1O</smiles>

(54)<smiles>O=C(/C=C/c1ccc(O)c(O)c1)OC1[C@H](O)CC(O)(C(=O)O)C[C@H]1O</smiles> 
<smiles>O=C(/C=C/c1ccc(O)c(O)c1)OC1CC2(O)CC(=O)C(O)C1C(O)C2O</smiles>

(56)<smiles>CC1=C[C@@H](O)CC(C)(C)C1/C=C/C(C)=C/C=C/C(C)=C/C=C/C=C(C)/C=C/C=C(C)/C=C/C1=C(C)C[C@@H](O)CC1(C)C</smiles>

(57)<smiles>C=C(C)C1C=C2C(O1)[C@H](C)[C@H](O)CC2(C)C</smiles>

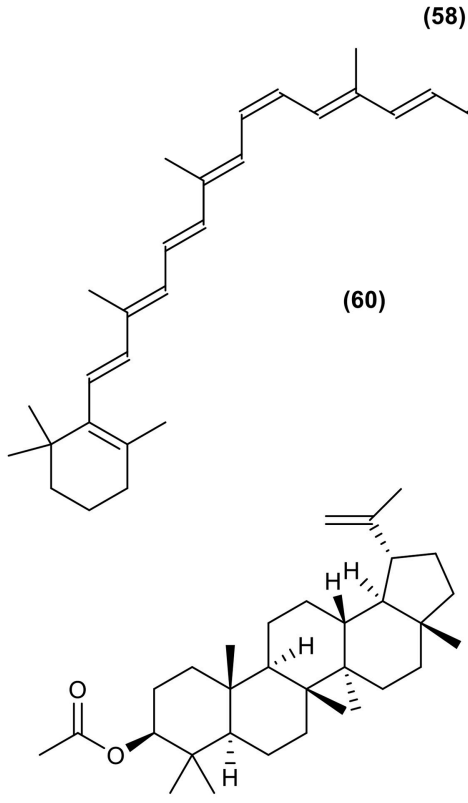

(62)<smiles>C[C@H]1O[C@H](Oc2ccc(CC(N)=O)cc2)[C@H](O)[C@H](O)[C@@H]1O</smiles>

(65)

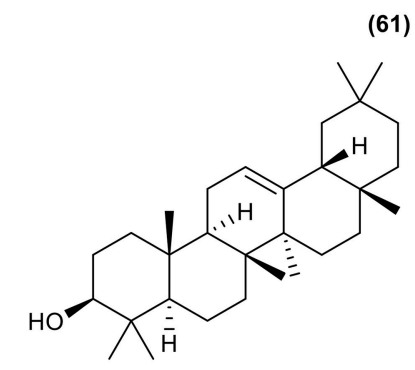

(63)<smiles>C[C@@H]1O[C@H](Oc2ccc(CC(N)=O)cc2)[C@H](O)[C@H](O[C@H]2C[C@H](CO)[C@@H](O)[C@H](O)[C@H]2O)[C@H]1O</smiles>

(66)

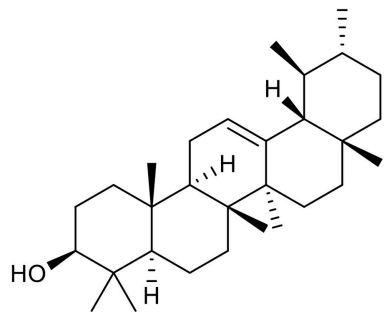

(64)

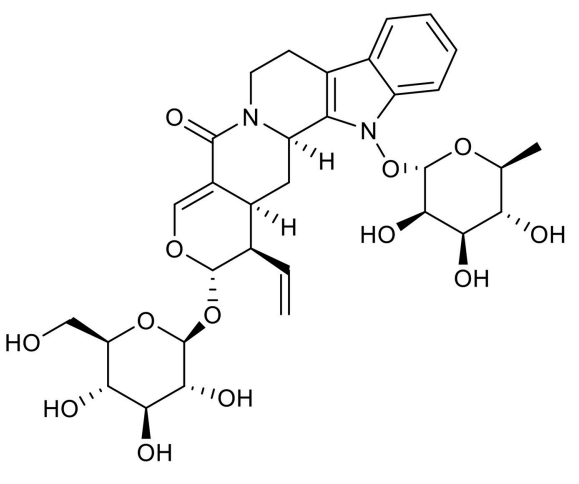


<smiles>CCCC(=O)N(C)C(C)=O</smiles>

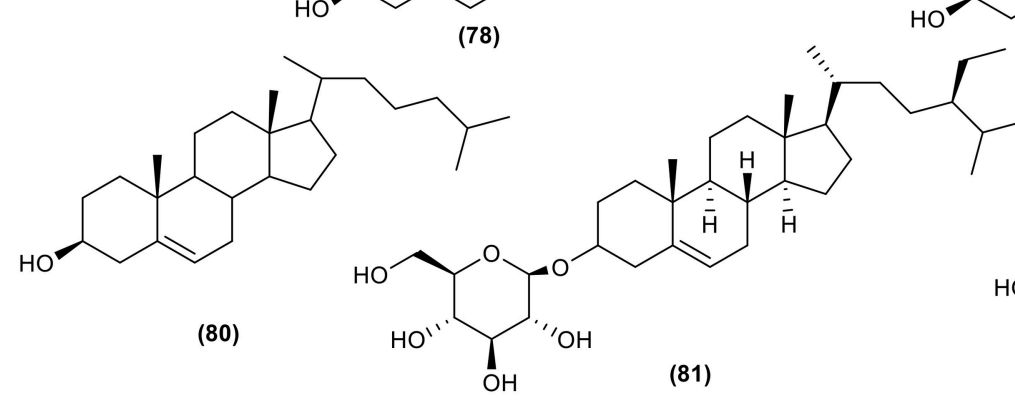<smiles>CCSC(=O)NCc1ccccc1</smiles><smiles>O=C(NCc1ccccc1)NCc1ccccc1</smiles>

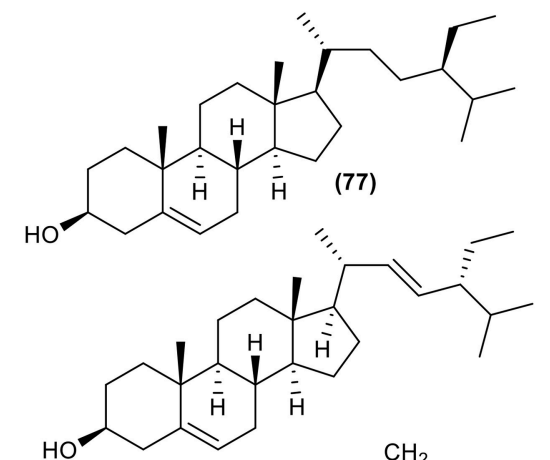

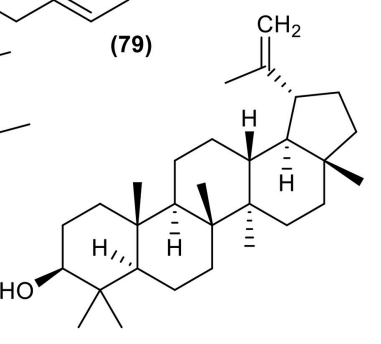<smiles>CCCC=CCCCCCCCC(=O)O</smiles>

(83)<smiles>CCCCCCCCCCCCCCCCC=CCCCCCCCCC(=O)O</smiles>

(84)

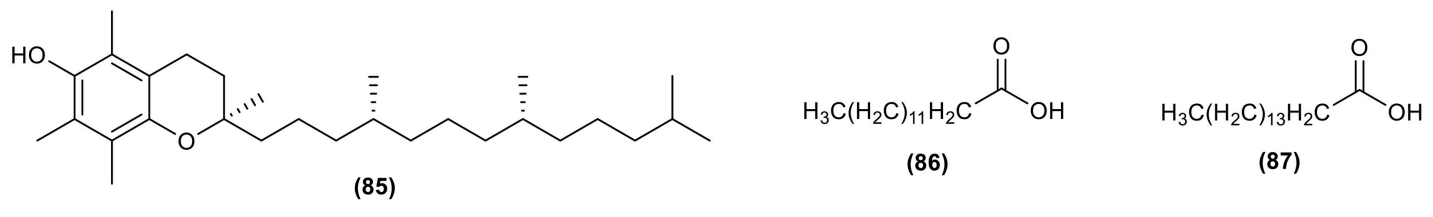<smiles>CCCCC=CCCCCCCCCCCC(=O)O</smiles>

(88)<smiles>CC/C=C/C/C=C/C/C=C/CCCC(=O)O</smiles>

(91)<smiles>CCCCCCCCCCCCCCCCCC(=O)O</smiles>

(89)
$\mathrm{H}_{3} \mathrm{C}\left(\mathrm{H}_{2} \mathrm{C}\right)_{19} \mathrm{H}_{2} \mathrm{C} \stackrel{\text { 岸 }}{\mathrm{OH}}$

(92) 
<smiles>CCCCCC/C=C\CCCCCCCCCCCC(=O)O</smiles><smiles>[R]c1ccc([R])cc1</smiles>

\begin{tabular}{ccc}
\hline & $\mathrm{R}_{1}$ & $\mathrm{R}_{2}$ \\
\hline $\mathbf{9 4}$ & $\mathrm{CO}_{2} \mathrm{H}$ & O-Glucose \\
$\mathbf{9 5}$ & $\mathrm{CO}_{2} \mathrm{H}$ & O- \\
& & $\begin{array}{c}\text { Rhamnosyl- } \\
\left(1^{\prime \prime} \rightarrow 2^{\prime}\right)-\end{array}$ \\
& & glucose \\
$\mathbf{9 6}$ & $\mathrm{CHO}$ & O-Glucose \\
\hline
\end{tabular}

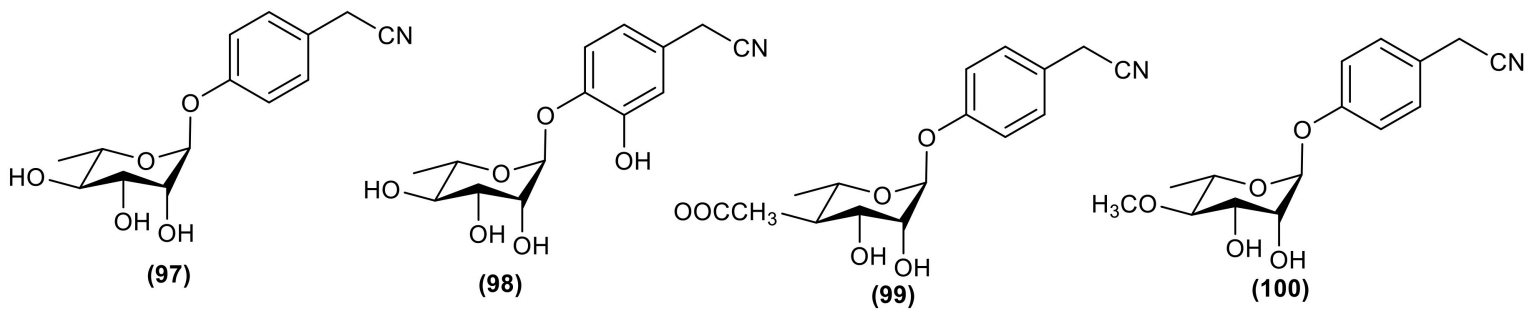<smiles>Cc1cccc(C)c1C(=O)OC1OC(CO)C(O)C(O)C1O</smiles><smiles>CC1=CCC(C(C)C)C=C1</smiles><smiles>C=CCc1ccc(O)c(OC)c1</smiles><smiles>COc1cc(C=O)ccc1O</smiles>

(101)

(102)

(103)<smiles>CCCCC/C=C\C/C=C\CCCCCCCC(=O)OCC(COC(=O)CCCCCCC/C=C\C/C=C\CCCCCC)OC(=O)CCCCCCCCCC</smiles><smiles>COc1ccc(-c2cc(=O)c3c(O)c(OC)c(O)c(C(O)C(O)C(O)CO)c3o2)cc1</smiles><smiles>NCc1ccccc1</smiles>

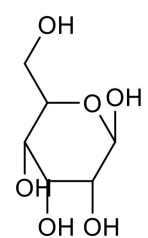

(109)
(107)<smiles>CCCCCCCC/C=C\CCCCCCCC(=O)OCC(COC(=O)CCCCCCC/C=C\CCCCCCCC)OC(=O)CCCCCCCCC</smiles>

(110)

FIGURE 1 | Structures of compounds from Moringa species.

Dehshahri et al. (2012a) initiated an in vitro callus culture study of $M$. peregrina to induce the production of isothiocyanates but the study did not manage to produce any. Isothiocyanate is commonly present as a volatile oil and is not stable at room temperature. In contrast, $M$. oleifera's isothiocyanate is very stable and present as a solid at room temperature because of the additional sugar moiety on its structure (Tumer et al., 2015).

\section{Phenolic Acid}

M. oleifera leaves contain gallic acid (44) as their major phenolic acid. Ellagic acid (48), ferulic acid (49), caffeic acid (50), o-coumaric acid (51), and chlorogenic acid (54), are also detected in the leaves and gentisic acid (46), syringic acid (47), $\rho$-coumaric acid (52), and sinapic acid (53) were detected in trace amounts (Leone et al., 2015a,b). Other phenolic 
TABLE 3 | Chemical constituents of Moringa species.

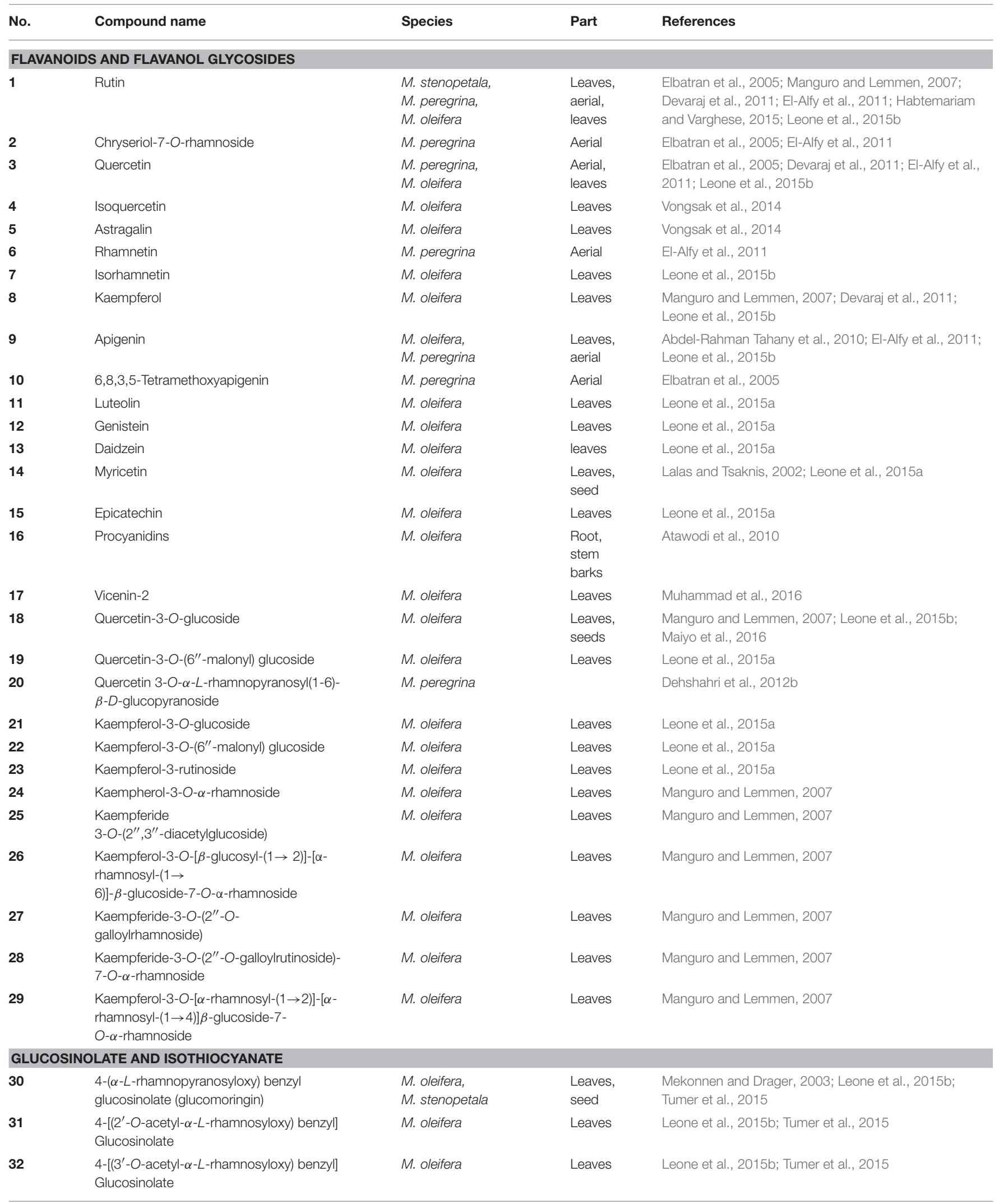


TABLE 3 | Continued

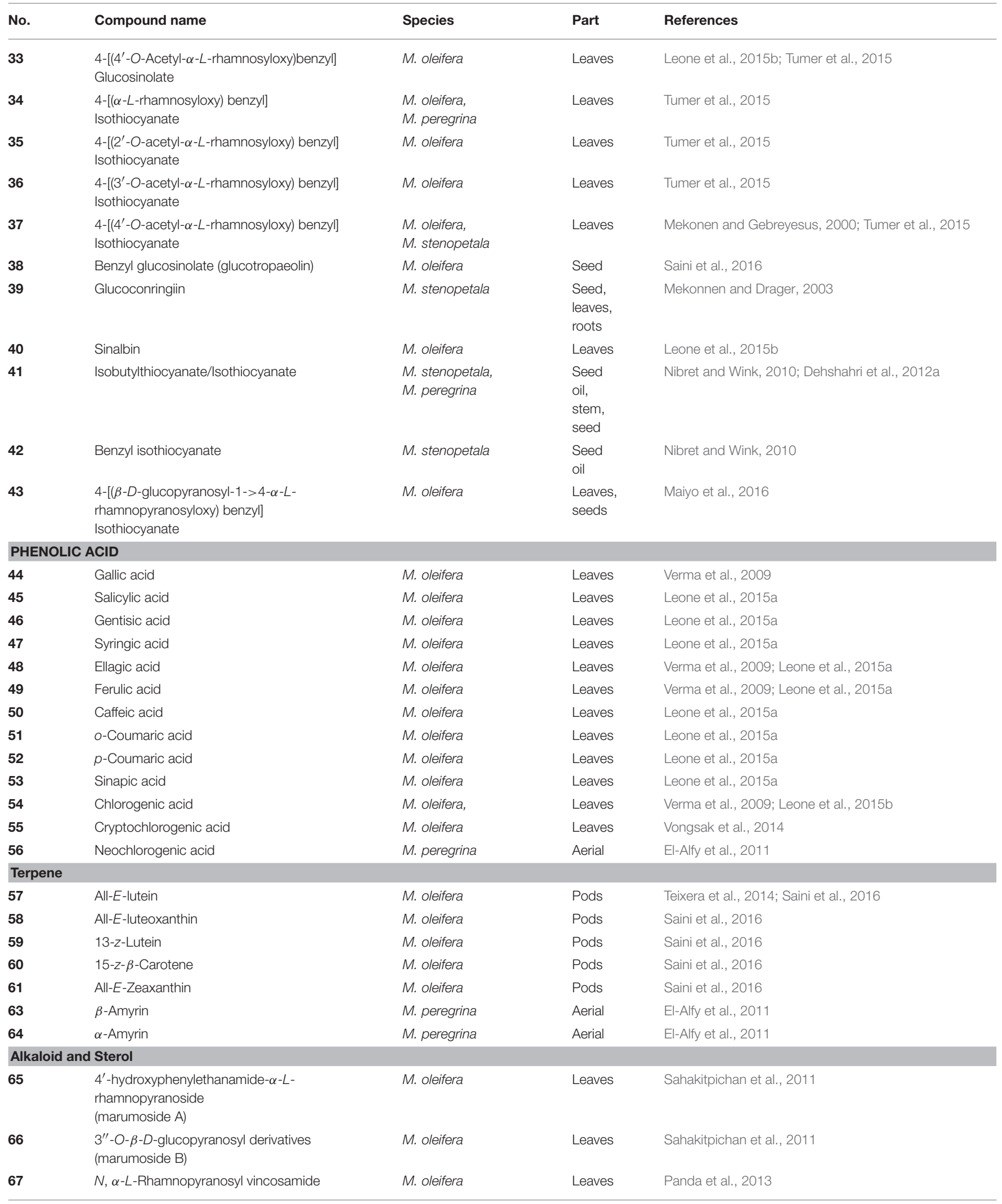


TABLE 3 | Continued

\begin{tabular}{|c|c|c|c|c|}
\hline No. & Compound name & Species & Part & References \\
\hline 70 & 5,5-Dimethyloxazolidine-2-thione & M. stenopetala & Seeds & Mekonnen and Drager, 2003 \\
\hline 71 & $\begin{array}{l}\text { O-Ethyl-4-[( } \alpha \text { - L-rhamnosyloxy)-benzyl] } \\
\text { carbamate }\end{array}$ & M. oleifera & Seeds & Guevara et al., 1999 \\
\hline 73 & $\mathrm{~N}$-benzyl, S-ethylthioformate & M. oleifera & $\begin{array}{l}\text { Root } \\
\text { bark }\end{array}$ & Nikkon et al., 2003 \\
\hline 74 & 1, 3-Dibenzyl urea & M. oleifera & Roots & Sashidara et al., 2009 \\
\hline 75 & Pterygospermin & M. oleifera & Seeds & Das et al., 1957 \\
\hline 76 & Niaziminin & M. oleifera & Leaves & Murakami et al., 1998 \\
\hline 78 & Campesterol & M. peregrina, & Oil & Abd El Baky and El-Baroty, 2013 \\
\hline 79 & Stigmasterol & M. peregrina, & Oil & Abd El Baky and El-Baroty, 2013 \\
\hline 80 & Cholest-5-en-3-ol & M. stenopetala & Root & Tesemma et al., 2013 \\
\hline 81 & $\beta$-Sitosterol-3-O- $\beta$ - $D$-galactopyranoside & $\begin{array}{l}\text { M. oleifera, } \\
\text { M. peregrina }\end{array}$ & $\begin{array}{l}\text { Stem } \\
\text { bark }\end{array}$ & $\begin{array}{l}\text { Abdel-Rahman Tahany et al., 2010; Bargah and Das, } \\
2014\end{array}$ \\
\hline 82 & Lupeol & M. peregrina & Leaves & Safaeian et al., 2015 \\
\hline \multicolumn{5}{|c|}{ OTHERS } \\
\hline 83 & Oleic acid & $\begin{array}{l}\text { M. oleifera, } \\
\text { M. drouhardii, } \\
\text { M. ovalifolia, } \\
\text { M. peregrina, } \\
\text { M. stenopetala, } \\
\text { M. concanensis, } \\
\text { M. hildebrandtii }\end{array}$ & $\begin{array}{l}\text { Oil, } \\
\text { oil, oil }\end{array}$ & $\begin{array}{l}\text { Kleiman et al., 2008; Nibret and Wink, 2010; Gaikwad } \\
\text { et al., 2011; Abd El Baky and El-Baroty, } 2013\end{array}$ \\
\hline 85 & Tocopherols & M. concanensis & Leaves & Vijayakumar and Sumathi, 2016 \\
\hline 86 & Myristic acid & $\begin{array}{l}\text { M. oleifera, } \\
\text { M. drouhardii, } \\
\text { M. ovalifolia, } \\
\text { M. peregrina, } \\
\text { M. stenopetala, } \\
\text { M. hildebrandtii }\end{array}$ & Oil & $\begin{array}{l}\text { Kleiman et al., 2008; Nibret and Wink, 2010; Abd El } \\
\text { Baky and El-Baroty, } 2013\end{array}$ \\
\hline 87 & Palmitic acid & $\begin{array}{l}\text { M. oleifera, } \\
\text { M. drouhardii, } \\
\text { M. ovalifolia, } \\
\text { M. peregrina, } \\
\text { M. stenopetala, } \\
\text { M. concanensis, } \\
\text { M. hildebrandtii }\end{array}$ & $\begin{array}{l}\text { Oil, } \\
\text { roots }\end{array}$ & $\begin{array}{l}\text { Kleiman et al., 2008; Nibret and Wink, 2010; Abd El } \\
\text { Baky and El-Baroty, 2013; Faizi et al., } 2014\end{array}$ \\
\hline 88 & Palmitoleic acid & $\begin{array}{l}\text { M. oleifera, } \\
\text { M. drouhardii, } \\
\text { M. ovalifolia, } \\
\text { M. peregrina, } \\
\text { M. stenopetala, } \\
\text { M. concanensis }\end{array}$ & Oil & Abd El Baky and El-Baroty, 2013 \\
\hline
\end{tabular}


TABLE 3 | Continued

\begin{tabular}{|c|c|c|c|c|}
\hline No. & Compound name & Species & Part & References \\
\hline 89 & Stearic acid & $\begin{array}{l}\text { M. oleifera, } \\
\text { M. drouhardii, } \\
\text { M. ovalifolia, } \\
\text { M. peregrina, } \\
\text { M. stenopetala, } \\
\text { M. concanensis, } \\
\text { M. hildebrandtii }\end{array}$ & Oil & Kleiman et al., 2008; Abd El Baky and El-Baroty, 2013 \\
\hline 92 & Behenic acid & $\begin{array}{l}\text { M. oleifera, } \\
\text { M. drouhardii, } \\
\text { M. ovalifolia, } \\
\text { M. peregrina, } \\
\text { M. stenopetala, } \\
\text { M. concanensis, } \\
\text { M. hildebrandtii }\end{array}$ & Oil & Kleiman et al., 2008; Abd El Baky and El-Baroty, 2013 \\
\hline 93 & Paullinic acid & $\begin{array}{l}\text { M. oleifera, } \\
\text { M. drouhardii, } \\
\text { M. ovalifolia, } \\
\text { M. peregrina, } \\
\text { M. stenopetala, } \\
\text { M. concanensis, } \\
\text { M. hildebrandtii }\end{array}$ & Oil & Kleiman et al., 2008; Abd El Baky and El-Baroty, 2013 \\
\hline 98 & Niaziridin & M. oleifera & $\begin{array}{l}\text { Pods, } \\
\text { leaves }\end{array}$ & Shanker et al., 2007 \\
\hline 99 & Niazirinin & M. oleifera & Leaves & Faizi et al., 1994 \\
\hline 100 & $\begin{array}{l}\text { 4-( } 4^{\prime}-O-\text { methyl- } \alpha \text {-L-rhamnosyloxy) } \\
\text { benzyl nitrile }\end{array}$ & M. peregrina & Seeds & El-Haddad et al., 2002 \\
\hline 101 & Moringyne & M. oleifera & Seeds & Memon et al., 1985 \\
\hline 102 & $\alpha$-Phellandrene & M. oleifera & Oil & Ogunbino et al., 2009 \\
\hline 103 & p-Cymene & $\begin{array}{l}\text { M. peregrina, } \\
\text { M. oleifera }\end{array}$ & $\begin{array}{l}\text { Seed, } \\
\text { oil }\end{array}$ & Ogunbino et al., 2009; Dehshahri et al., 2012a \\
\hline 104 & Eugenol & M. oleifera & Bark & Al-Asmari et al., 2015 \\
\hline 105 & Vanillin & M. oleifera & $\begin{array}{l}\text { Leaves, } \\
\text { fruits, } \\
\text { seed }\end{array}$ & Singh et al., 2009 \\
\hline 106 & 1,3-Dilinoleoyl-2-olein & M. stenopetala & Roots & Bekele et al., 2013 \\
\hline 107 & 6-Methoxy-acacetin-8-C- $\beta$-glucoside & M. peregrina & Aerial & El-Alfy et al., 2011 \\
\hline 108 & Benzylamine & M. oleifera & & Iffiu-Soltesz et al., 2010 \\
\hline 109 & $D$-allose & M. oleifera & Leaves & Al-Asmari et al., 2015 \\
\hline 110 & 1,3-Dioleoyl-2-linolein & M. stenopetala & Roots & Bekele et al., 2013 \\
\hline
\end{tabular}


acid constituents in the species are tabulated in Figure $\mathbf{1}$ and Table 3.

\section{Terpenes}

Teixera et al. (2014) and Saini et al. (2014) reported that the major carotenoid detected in M. oleifera leaves is lutein (57). Saini et al. (2014) reported that $M$. oleifera did not contain $\alpha$-carotene which can usually be found in green leafy plants. The author assumed that all of the $\alpha$-carotene had been fully converted into lutein. Other carotenoids that can be found in the plant are all$E$-luteoxanthin (58), 13-Z-lutein (59), 15-Z- $\beta$-carotene (60), and all-E-zeaxanthin (61) (Saini et al., 2014). Lupeol acetate (62), $\beta$ amyrin (63), and $\alpha$-amyrin (64) were isolated from an $n$-hexane fraction of an ethanol extract of the aerial part of $M$. peregrina (El-Alfy et al., 2011).

\section{Alkaloids}

Two new pyrrole alkaloid glycosides were isolated from $M$. oleifera leaves, marumoside A (65) and marumoside B (66) together with pyrrolemarumine- $4^{\prime \prime}-O-\alpha-L$-rhamnopyranoside (68) (Sahakitpichan et al., 2011).

\section{Sterols}

A sterol glycoside, namely $\beta$-sitosterol-3-O- $\beta$ - $D$ galactopyranoside (81), was isolated from a chloroform extract of M. oleifera stem bark (Bargah and Das, 2014). The main steroidal components in $M$. peregrina oil were $\beta$-sitosterol (77) (56.76\%), campesterol (78) (23.24\%), and stigmasterol (79) (8.11\%) (Abd El Baky and El-Baroty, 2013). $\beta$-sitosterol (77) was isolated from the leaves and seeds of $M$. oleifera (Maiyo et al., 2016) and an acetone extract of $M$. stenopetala root wood has been reported to contain cholest-5-en-3-ol (80) (Tesemma et al., 2013).

\section{Others}

Shanker et al. (2007) reported that two nitrile glycosides, niazirin (97) and niaziridin (98), were observed by reverse phase HPLC. From the three parts of $M$. oleifera tested, only the leaves and pods showed peaks for these nitrile glycosides while no corresponding peaks were detected from the bark. The content of niazirin (97) was higher in the leaves while the pods contained a higher concentration of niaziridin (98). 6-methoxy-acacetin-8$\mathrm{C}$ - $\beta$-glucoside (107) was first isolated from an ethanolic extract of the aerial part of M. peregrina (El-Alfy et al., 2011).

The major fatty acids of $M$. peregrina are oleic acid (18:1) (83) $65.36 \%$ and linoleic acid (18:3) (84) 15.32\%. The oil also contains a high content of tocopherols (85) and phenols (Abd El Baky and El-Baroty, 2013). Oleic acid (83) (18:1), linoleic acid (84) (18:2), myristic acid (86) (14:0), palmitic acid (87) (16:0), palmitoleic acid (88) (16:1), stearic acid (89) (18:0), arachidic acid (90) (20:0), linolenic acid (91) (18:3), behenic acid (92) (22:0), and paullinic acid (93) (20:1) are present in M. oleifera, M. drouhardii, M. ovalifolia, M. peregrina, and M. stenopetala. $M$. concanensis contains all the fatty acids listed above except myristic acid (86) and linolenic acid (91). M. hildebrandtii also contains all the fatty acids listed except for palmitoleic acid (88) and linolenic acid (91) (Kleiman et al., 2008). The species contain high oleic acid (83) levels from 68 to $79 \%$. However, the fatty acid content is dependent on the location where the oil is obtained. M. oleifera seed oil has a nutty flavor and has light yellow color (Nadeem and Imran, 2016). The oil contains a high concentration of oleic acid (83) which constitutes $75-77 \%$ of the fatty acid composition of the seeds.

\section{BIOLOGICAL ACTIVITIES}

\section{Antioxidant}

The high phenolic content of Moringa species contributes to their high antioxidant activity. Phenolic compounds stabilize radicals produced in cells by donating or accepting electrons, hence acting as antioxidants. A water extract of $M$. stenopetala leaves had higher DPPH (1,1-di-phenyl-2-picrylhydrazyl) inhibition ( $\mathrm{IC}_{50}$ : $40 \mu \mathrm{g} / \mathrm{mL}$ ) than a similar extract of $M$. oleifera leaves ( $\mathrm{IC}_{50}$ : $215 \mu \mathrm{g} / \mathrm{mL}$ ). Rutin (1) also possessed high antioxidant activity $\left(\mathrm{IC}_{50}: 5 \mu \mathrm{g} / \mathrm{mL}\right)$ in a DPPH assay. An HPLC analysis showed a higher content of rutin (1) in $M$. stenopetala, making it a stronger antioxidant than $M$. oleifera (Habtemariam and Varghese, 2015). A methanol fraction of $M$. peregrina leaves showed DPPH inhibition ( $\mathrm{IC}_{50}: 17.07 \mu \mathrm{g} / \mathrm{mL}$ ) which was comparable to ascorbic acid's DPPH inhibition ( $\mathrm{IC}_{50}: 13.68 \mu \mathrm{g} / \mathrm{mL}$ ) (AlOwaisi et al., 2014). Based on HPLC results, M. peregrina leaves' hexane fraction did not contain phenolic compounds, but did possess radical scavenging activity. Abd El Baky and El-Baroty (2013) reported that $M$. peregrina seed oil also had significant antioxidant activity compared to the common antioxidants BHA, $\alpha$-tocopherol, and BHT. M. ovalifolia, specifically its bark, contained quercetin (3), kaempferol (8), and myricetin (14) that showed antioxidant activity by increasing ferric reducing activity and inhibiting DPPH activity (Ananias, 2015). A study reported that pre-treatment of $M$. peregrina leaves could prevent the plasma hydrogen peroxide concentration from rising at doses of 200 and $400 \mathrm{mg} / \mathrm{kg}$ (Safaeian et al., 2015). It also reduced the elevated hydrogen peroxide concentration in plasma and increased the ferric reducing antioxidant at doses of $400 \mathrm{mg} / \mathrm{kg}$. Santhi and Sengottuvel (2016) reported that a methanol extract of M. concanensis leaves inhibited DPPH activity, hydroxyl radicals, reducing power, and superoxide anion radicals. The hydroxyl radical inhibition of the extract ( $\mathrm{IC}_{50}: 45.3 \mu \mathrm{g} / \mathrm{mL}$ ) was stronger than that of ascorbic acid $\left(\mathrm{IC}_{50}: 58.2 \mu \mathrm{g} / \mathrm{mL}\right.$ ). Ndhlala et al. (2014) studied the phytochemical properties, and the antioxidant and antimicrobial activities of $M$. oleifera from 13 different cultivars around the world. It was found that $M$. oleifera from different cultivars had different antioxidant, phytochemical, and antimicrobial profiles. M. oleifera from one of Thailand's cultivars was five times stronger in inhibiting DPPH radical scavenging activity than ascorbic acid was.

Verma et al. (2009) reported that the most active fraction of a $M$. oleifera leaf hydromethanolic extract was the ethyl acetate fraction. The fraction inhibited $\mathrm{DPPH}$ by $\mathrm{IC}_{50}$ at 0.04 $\mathrm{mg} / \mathrm{mL}$, which was comparable with quercetin (3) activity that had inhibited DPPH with an $\mathrm{IC}_{50}$-value of $0.02 \mathrm{mg} / \mathrm{mL}$. As well as in-vitro tests, the ethyl acetate fraction of M. oleifera leaves has been tested on $\mathrm{CCl}_{4}$ intoxicated rats (Verma et al., 2009). The extract increased superoxide dismutase (SOD), catalase (CAT), 
and reduced glutathione (GSH) levels. Pre-treatment of the $M$. oleifera leaf hydroethanolic extract also counteracted hepatoxicity induced by paracetamol in Sprague-Dawley rats by reducing lipid peroxidation levels and normalizing antioxidant enzyme levels (Uma et al., 2010). A study observed that M. oleifera leaf extract reduced DNA breakage in KB cells in addition to increasing their antioxidant enzymes and inhibiting lipid peroxidation (Sreelatha and Padma, 2011). The antioxidant activity of leaf, oil, and seed ethanolic extracts of $M$. oleifera have been reported to display renal protective and hepatoprotective activity against gamma radiation, $\mathrm{HgCl}_{2}$, acetaminophen, and arsenic (Gupta et al., 2007; Fakurazi et al., 2008; Sinha et al., 2011; Abarikwu et al., 2017). Agrawal et al. (2015) observed that M. oleifera hydro alcoholic root extract acted synergistically with curcumin and with piperine in inhibiting oxidative stress induced by beryllium in rats. By controlling GSH level, $M$. oleifera ethanol extract reduced glucose-induced cataractogenesis of isolated goat eye lenses (Kurmi et al., 2014). This activity was also observed in the flavonoid fraction of the M. oleifera leaves that reduced seleniteinduced cataractogenesis in rat pups (Sasikala et al., 2010).

A study stated that myricetin (14) from $M$. oleifera seeds had stronger antioxidant activity than $\alpha$-tocopherol and BHT (Lalas and Tsaknis, 2002). A leaf extract of M. oleifera contained isoquercetin (4), astragalin (5), and crypto-chlorogenic acid (54). The leaf extract of the plant, together with the compounds, reduced reactive oxygen species in HEK-293 cells that were induced by $\mathrm{H}_{2} \mathrm{O}_{2}$ (Vongsak et al., 2015). The compound that had the highest antioxidant activity was determined to be isoquercetin (4) as it increased the mRNA expression levels of CAT, heme oxygenase 1 , and SOD. Maiyo et al. (2016) isolated two compounds from M. oleifera seeds and leaves that showed antioxidant activity: quercetin3-O-glucoside (18) displayed significant antioxidant activity while 4 -( $\beta$ - $D$-glucopyranosyl-1->4- $\alpha$ - $L$-rhamnopyranosyloxy) benzylisothiocyanate (43)'s activity was moderate.

Ngamukote et al. (2016) conducted a study on the effects of $M$. oleifera extract on the fasting plasma glucose (FPG) concentrations of healthy volunteers, in addition to its antioxidant activity. The extract reduced plasma malondialdehyde (MDA) levels, increased Trolox equivalent antioxidant activity, increased the ferric reducing ability of the plasma, and did not change the FPG concentration compared with that of healthy volunteers that were fed only warm water.

\section{Anti-convulsant}

Experiments to discern the effects of $M$. concanensis leaf ethanol extract on the maximal electroshock seizure test and the pentylene tetrazole-induced convulsion test were conducted on Swiss albino mice (Joy et al., 2013). For both of the tests, M. concanensis inhibited mortality compared to control group in which deaths resulted. The study reported that the extract might block either calcium channels, sodium channels, or NMDA receptors, or has GABA agonist activity.

\section{Anticancer}

The main pathway for the anticancer activity of Moringa species is by inhibiting proliferation through apoptosis. Table 4 summarizes the cancerous cell lines that have been inhibited by Moringa species. Methanol crude extracts of M. concanensis root bark inhibited the proliferation of hepatocellular carcinoma (Hep-G2) cells through intrinsic pathways by regulating caspase 9 and caspase 3 while reducing the mitochondrial membrane potential of the cells (Vijayarajan and Pandian, 2016). (4'-Oacetyl- $\alpha$ - $L$-rhamnopyranosyloxy)benzyl isothiocyanate (37) and niazimicin (70) were responsible for the regulation of caspase 9 activity (Tiloke et al., 2013). M. oleifera leaf extract decreased the proliferation of B16F10 melanoma cells in addition to causing roughly $22 \%$ cancerous cell death (Gismondi et al., 2013). It caused apoptosis at the sub G1-area and induced cell arrest at the G2/M phase. The extract increased the $\mathrm{p} 27^{\mathrm{Kip} 1}, \mathrm{p}^{53}$, and $\mathrm{p} 21^{\mathrm{WAF1} / \mathrm{Cip} 1}$ levels of the cells. Moringin (34) inhibited malignant astrocytoma cells by oxidative stressmediated apoptosis through Bax and p53 activation pathways (Rajan et al., 2016). Nibret and Wink (2010) reported that seed oil from M. stenopetala inhibited the proliferation of HL-60 cells with $\mathrm{IC}_{50}: 11.63 \mu \mathrm{g} / \mathrm{mL}$. The bioactive compound reported was benzyl isothiocyanate (42), that had high cytotoxic activity against HL-60 cell with $\mathrm{IC}_{50}: 4.62 \mu \mathrm{g} / \mathrm{mL}$.

An ethanol extract of $M$. stenopetala leaves and seeds reduced Hep-G2 activity and increased LDH leakage in a dose and time-dependent manner (Mekonnen et al., 2005). 4 -( $\beta$-D-glucopyranosyl-1->4- $\alpha$-rhamnopyranosyloxy)-

benzylisothiocyanate (43) had stronger anticancer activity than quercetin-3-O-glucoside (18) against Caco-2 and Hep-G2 cells (Maiyo et al., 2016). The presence of eugenol (101) in M. oleifera bark inhibited the activity of E2F1/survivin and the presence of $D$-allose (109) in $M$. oleifera leaves inhibited cancer cells in the G1 phase of MDA-MB-231 and HCT-8 cells (Al-Asmari et al., 2015).

A water extract of $M$. oleifera pods exhibited suppressive effects on dextran sodium sulfate- and azoxymethane-induced mouse colon carcinogenesis (Budda et al., 2011). The extract reduced COX-2 proteins and iNOS expression in addition to reducing the PCNA index of the mice. The extract also reduced the multiplicity and incidence of the tumors. The study reported that the high content of omega-9 oleic fatty acid (83) in the extract, that possesses anti-inflammatory activity, could modulate this cell proliferation. Alternately, glucomoringin (30) might also be responsible for this antitumor activity.

A hydro alcoholic extract of $M$. oleifera also exhibited antitumorigenic activity by balancing xenobiotic metabolism between Phase I and Phase II (Bharali et al., 2003). The extract increased Cyt P450 and Cyt b5 activity in Phase I while increasing glutathione S-transferase, glutathione reductase, and glutathione peroxidase, and reducing the GSH levels that are responsible for Phase II. The study also reported that the extract might act as a "blocking agent" in reducing xenobiotic substrates for Phase II. In addition, the extract increased CAT concentration while reducing mouse skin papilloma genesis and lipid peroxidation.

\section{Antimicrobial}

Various research has been conducted on Moringa species for their antimicrobial activity. Table 5 summarizes the antimicrobial 
TABLE 4 | Cell line studied for anticancer activity of Moringa species.

\begin{tabular}{lll}
\hline Species & Cancerous cell line inhibited & References \\
\hline M. concanensis & Hep G2 & Vijayarajan and Pandian, \\
M. oleifera & A549, Hep-G2, Panc-1, p34, & Monera et al., 2008; \\
& COLO 357, MDA-MB-231, & Waiyaput et al., 2012; \\
& HCT-8, MCF-7, HeLa, CACO-2, & Berkovich et al., 2013; \\
& L929, HCT-16, PC3, K562, & Tiloke et al., 2013; \\
& THP-1, T47D, HL-60, Colo-205 & Al-Asmari et al., 2015; Diab \\
& & et al., 2015; Elsayed et al., \\
& & 2015; Jung et al., 2015; \\
& & Madi et al., 2016 \\
M. peregrina & MCF-7, Hep G2, HCT 116 & El-Alfy et al., 2011; Abd El \\
& & Baky and El-Baroty, 2013 \\
M. stenopetala & HL-60, Hep-G2 & Mekonnen et al., 2005; \\
& & Nibret and Wink, 2010 \\
\hline
\end{tabular}

activity of each species. Moringa species have been widely used as water purifiers and antiseptics for water treatment because of their high antimicrobial activity. Hexane and methanol seed extracts of both $M$. oleifera and $M$. stenopetala showed inhibition against waterborne pathogens, particularly against Salmonella typhii, Vibrio cholera, and Escherichia coli (Walter et al., 2011). Most of the extracts showed better inhibition in lower concentrations.

Ethyl acetate, acetone, and ethanol extracts of $M$. oleifera seeds, roots, leaves, and a mixture, were assessed for their dental antibacterial and antifungal activity (Elgamily et al., 2016). All of the extracts showed inhibition of Streptococcus aureus and Streptococcus mutans with the ethanol extract and leaf extract showing the highest inhibition. In contrast, none of the extracts showed inhibition against Candida albicans. Another study reported that higher concentrations of $M$. oleifera seeds were needed to inhibit the growth of $C$. albicans (Saadabi and Abu Zaid, 2011). The ethanolic leaf extract of $M$. oleifera was formulated into mouthwash and toothpaste (Elgamily et al., 2016). As a result, the toothpaste showed inhibition of Streptococcus aureus, S. mutans, and C. albicans, but the mouthwash only showed antimicrobial activity. The ethanol extracts of the seeds and leaves of $M$. oleifera also exhibited inhibition against the dermatophytes Trichophyton mentagrophytes, Microsporum canis, Trichophyton rubrum, and Epidermophyton floccosum (Chuang et al., 2007).

Hexane, ethyl acetate, methanol, and chloroform extracts of M. oleifera leaves were also tested on different diarrhea associated bacteria: Serratia marcescens, Shigella dysenteriae, Enterobacter sp., E. coli, Klebsiella pneumoniae, and Salmonella sp. (Rahman et al., 2010). All of the extracts exhibited antibacterial activity against the bacteria with minimum inhibitory concentrations ranging from 62.5 to $1,000 \mu \mathrm{g} / \mathrm{mL}$ and zones of inhibition of $8-23.2 \mathrm{~mm}$. Peixoto et al. (2011) reported that aqueous and ethanolic extracts of $M$. oleifera leaves showed inhibition against Staphylococcus aureus, Vibrio parahaemolyticus, Enterococcus faecalis, and Aeromonas caviae. In contrast, the extracts showed negative result on E. coli, Salmonella enteritidis, and Pseudomonas aeruginosa. Throughout the study it was observed that the extract showed stronger inhibition against gram-positive species than gram-negative species.

The bioactive compounds isolated from $M$. stenopetala were cholest-5-en-3-ol (80), oleic acid (83), and palmitic acid (87) (Tesemma et al., 2013). From the compounds listed, cholest-5en-3-ol (80) possessed the strongest antibacterial activity against E. coli. Abdel-Rahman Tahany et al. (2010) isolated lupeol acetate (62), $\beta$-amyrin (63), $\alpha$-amyrin (64), $\beta$-sitosterol (77), and $\beta$-sitosterol-3-O- $\beta$-D-glucoside (81) from $M$. peregrina and these compounds showed higher inhibition toward bacteria than toward fungi. $\beta$-Sitosterol (77) and $\beta$-sitosterol-3- $O-\beta$ - $D$ glucoside (81), particularly, only possessed antibacterial activity. It was also reported that $M$. concanensis showed a synergistic effect with Hugonia mystax and Curcuma neilgherrensis with better activity against E. coli, $P$. aeruginosa, and K. pneumoniae than when tested alone against the bacteria (Karmegam and Nagaraj, 2017).

Nikkon et al. (2003) isolated aglycon of deoxy-niazimicine (N-benzyl, S-ethyl thioformate) (73) from a chloroform extract of $M$. oleifera root bark and this compound showed stronger inhibition toward Staphylococcus aureus, S. dysenteriae, Shigella boydii, S. typhii, P. aeruginosa, C. albicans, and Aspergillus flavus growth than a crude extract. 4-[( $\alpha$ - $L$-rhamnosyloxy)benzyl] isothiocyanate (34) from $M$. oleifera and $M$. stenopetala seeds had minimal bactericidal concentrations of $56 \mu \mathrm{mol} / \mathrm{l}$ for Bacillus subtilis and $40 \mu \mathrm{mol} / \mathrm{l}$ for Mycobacterium phlei (Eilert et al., 2007). This isothiocyanate, together with 4-[(4'-O-acetyl$\alpha$-L-rhamnosyloxy)-benzyl] isothiocyanate (37) from $M$. oleifera seeds, exhibited antimicrobial activity against Staphylococcus aureus, Staphylococcus epidermis, B. subtilis, E. floccosum, and T. rubrum (Padla et al., 2012). Zaffer et al. (2014) reported that an ethyl acetate extract of $M$. oleifera bark showed higher inhibition toward Pseudomonas fluorescens, Staphylococcus aureus, Bacillus megaterium, and Citrobacter freundii than methanol, chloroform, and aqueous extracts of the same part of the plant.

Torondel et al. (2014) reported the effectiveness of dried and wet $M$. oleifera leaf powder as a hand-washing product in healthy volunteers. The results showed that, only the highest dose of $M$. oleifera, $4 \mathrm{~g}$, showed levels of inhibition of E. coli comparable to a non-medicated liquid soap. The study reported that this activity was not related to the mechanical friction produced while washing hands. As aqueous preparations of M. oleifera leaf powder exhibited stronger microbial inhibition than dried preparations, the study reported that this activity might be due to saponin presence in the extract that had surfactant properties.

\section{Antitrypanosomal}

In the Moringa genus, $M$. stenopetala showed significant antitrypanosomal activity. $M$. stenopetala leaf acetone extract and root ethanol extract inhibited the infective stages of Trypanosoma brucei (Mekonnen, 2002). A methanol extract of M. stenopetala maintained $100 \%$ survival against Trypanosoma congolense (Kifleyohannes et al., 2014). It also minimized PCV which is a method of controlling anemia. Dichloromethane and methane extracts of the seeds had low trypanocidal activity while the essential oils that contain mainly benzyl isothiocyanate (42) and isobutyl isothiocyanate (41) showed potent trypanocidal 
TABLE 5 | Microorganisms studied for antimicrobial activity of Moringa species.

\begin{tabular}{|c|c|c|}
\hline Species & Microorganism inhibited & References \\
\hline M. concanensis & $\begin{array}{l}\text { Proteus vulgaris, Lactobacillus brevis, Pseudomonas sp. Staphylococcus sp., Micrococcus luteus, } \\
\text { Bacillus sp., Lactobacillus bulgaricus, Aspergillus sojae, Aspergillus niger, Aspergillus oryzae, Aspergillus } \\
\text { flavus, Candida albicans, Vibrio cholera, Escherichia coli, Klebsiella pneumoniae, Pseudomonas } \\
\text { aeruginosa }\end{array}$ & $\begin{array}{l}\text { Balamurugan and Balakrishnan, } \\
\text { 2013; Karmegam and Nagaraj, } 2017\end{array}$ \\
\hline M. oleifera & $\begin{array}{l}\text { Aspergillus flavin, Trichoderma sp., Staphylococcus aureus, Shigella dysenteriae, Shigella boydii, Bacillus } \\
\text { megaterium, Escherichia coli, Enterobacter aerogenes, Providencia stuartii, Klebsiella pneumoniae, } \\
\text { Pseudomonas aeruginosa, Bacillus subtilis, Mycobacterium phlei, Bacillus cereus, Sarcina lutea, } \\
\text { Basidiobolus ranarum, Basidiobolus haptosporus, Propionibacterium acnes, Staph epidermis, Strep } \\
\text { pyogenes, Trichophyton mentagrophytes, Microsporum canis, Trichophyton rubrum, Epidermophyton } \\
\text { floccosum, Pseudomonas fluorescens, Citrobacter freundii, Serratia marcescens, Enterobacter sp., } \\
\text { Salmonella sp., Proteus vulgaris, Streptococcus mutans, Vibrio parahaemolyticus, Enterococcus } \\
\text { faecalis, Aeromonas cavieae, Streptococcus aureus, Streptococcus mutans, Penicillium expansum, } \\
\text { Penicillium digitatum, Penicillium aurantiogriseum, Penicillium citrinum, Aspergillus niger spp., Microcytis } \\
\text { aeruginosa, Salmonella typhii, Vibrio cholera, Candida albicans }\end{array}$ & $\begin{array}{l}\text { Nwosu and Okafor, 1995; Chuang } \\
\text { et al., 2007; Lurling and Beekman, } \\
\text { 2010; Rahman et al., 2010; Peixoto } \\
\text { et al., 2011; Saadabi and Abu Zaid, } \\
\text { 2011; Walter et al., 2011; Padla et al., } \\
\text { 2012; Rattanasena, 2012; Galuppo } \\
\text { et al., 2013; Marrufo et al., 2013; } \\
\text { Patel et al., 2014; Zaffer et al., 2014; } \\
\text { Eyarefe et al., 2015; Dzotam et al., } \\
\text { 2016; Elgamily et al., } 2016\end{array}$ \\
\hline M. ovalifolia & Escherichia coli, Bacillus cereus, Enterococcus faecalis & Shailemo et al., 2016 \\
\hline M. peregrina & $\begin{array}{l}\text { Escherichia coli, Staphylococcus aureus, Candida albicans, Pseudomonas aeruginosa, Staphylococcus } \\
\text { epidermis, Candida glabrata, Klebsiella pneumoniae, Enterobacter cloacae, Candida tropicalis, } \\
\text { Enterococcus sp., Aeromonas hydrophila }\end{array}$ & $\begin{array}{l}\text { Abdel-Rahman Tahany et al., 2010; } \\
\text { Lalas et al., 2012; El-Awady et al., } \\
2015\end{array}$ \\
\hline M. stenopetala & $\begin{array}{l}\text { Salmonella typhii, Vibrio cholera, Escherichia coli, Shigella spp., Staphylococcus aureus, Candida } \\
\text { albicans, Pseudomonad aeruginosa }\end{array}$ & $\begin{array}{l}\text { Walter et al., 2011; Tesemma et al., } \\
\text { 2013; Seifu, } 2014\end{array}$ \\
\hline
\end{tabular}

activity (Nibret and Wink, 2010). Petroleum ether, chloroform, methanol, and aqueous fractions of M. oleifera leaves, stem bark, and roots inhibited Trypanosoma brucei brucei (Ibrahim et al., 2014). Ayyari et al. (2013) reported that 4-[( $\alpha$ - $L$-rhamnosyloxy) benzyl] isothiocyanate (34) from $M$. peregrina aerial parts inhibited Trypanosoma brucei rhodesiense with an $\mathrm{IC}_{50}$ of $0.1 \mu \mathrm{M}$. With a dose $10 \mathrm{mg} / \mathrm{kg}$ for four consecutive days, the compound reduced parasitemia by $95 \%$ but the parasitemia increased again after 10 days of infection. The compound was reported to have the potential to become a high quality antitrypanosomal drug as it inhibited the parasite at specific enzymes and irreversibly inhibited trypanothione reductase. An acetone extract of $M$. stenopetala leaves and an ethanol extract of $M$. stenopetala root wood inhibited Trypanosoma brucei trypomastigotes with $\mathrm{ED}_{50}$-values of 10 and $9.2 \mu \mathrm{g} / \mathrm{mL}$, respectively (Mekonnen et al., 1999).

\section{Antileishmanial}

Mekonnen and Gessesse (1998) reported that high concentrations of $M$. stenopetala extract, 600 to $1,500 \mu \mathrm{g} / \mathrm{mL}$, changed Leishmania donovani promastigotes' shape and resulted in the loss to their flagella in $40-95 \%$ of them. A root extract of the plant inhibited Leishmanial aethiopica in mice (Bekele et al., 2013). 1,3-Dilinoleoyl-2-olein (106) and 1,3-dioleoyl-2-linolein (110) from the roots inhibited the promastigotes and amastigotes stages of the parasite. The activity of 1,3-Dilinoleoyl-2-olein (106) in inhibiting the promastigotes stage was comparable to that of the positive control, miltefosine.

Kaur et al. (2014) reported that a 70\% ethanolic extract of $M$. oleifera roots and a methanolic extract of $M$. oleifera leaves displayed antileishmanial activity against $L$. donovani promastigotes. The ethyl acetate fraction of a methanolic extract inhibited leishmaniasis with an $\mathrm{IC}_{50}$ of $27.5 \mu \mathrm{g} / \mathrm{mL}$. Niazinin, isolated from the ethyl acetate fraction, showed the most antileishmanial activity with an $\mathrm{IC}_{50}$ of $27.5 \mu \mathrm{g} / \mathrm{mL}$. Singh et al. (2015) observed antileishmanial activity from different parts of M. oleifera, the bark, leaf, stem, flower, and root. The flower, especially from the ethyl acetate fraction, showed the most potent activity against $L$. donovani promastigotes in infected macrophages by inhibiting parasite viability in a dose- and timedependent manner. The extract also reduced parasite activity in both the spleen and the liver of Balb/c mice.

\section{Antiviral}

M. oleifera extract possessed antiviral activity against the herpes simplex virus type 1 (HSV-1) by inhibiting more than $50 \%$ of plaque formation at a $100 \mu \mathrm{g} / \mathrm{mL}$ dose (Lipipun et al., 2003). The extract inhibited phosphonoacetate-resistant HSV-1 and kinasedeficient HSV-1 strains in mice. At a dose of $750 \mathrm{mg} / \mathrm{kg}$, the extract reduced the mortality of the infected mice by prolonging their mean survival time and delaying the development of skin lesions. An aqueous extract of M. oleifera leaves activated cellular immunity in mice that were infected with HSV-1 by reducing the virus concentration and limiting herpetic skin lesion development (Kurokawa et al., 2016). M. peregrina seed oil was also reported to have antiviral effects against HSV (Soltan and Zaki, 2009). Murakami et al. (1998) reported that 4-[(4'-Oacetyl-alpha- $L$-rhamnosyloxy) benzyl] isothiocyanate (37) and niaziminin (76) inhibited Epstein-Barr virus activation. $M$. oleifera also showed inhibition against the foot and mouth disease virus at concentrations of $1-50 \mu \mathrm{g} / \mathrm{mL}$ (Younus et al., 2016).

A buffer extract of $M$. oleifera fruits exhibited anti-HBV activity and a hydroalcoholic extract of the plant's leaves reduced the ccDNA level of HBV in HepG2 cells (Waiyaput et al., 2012). According to a survey, $M$. oleifera was being used as a supplement toward antiretroviral therapy for HIV infection, but no further research has been conducted on the efficiency of the plant as an antiviral substance (Monera and Maponga, 2010). 


\section{Antihyperglycemic, Antihyperlipidemic, and Hypocholesterolemic}

Ethanol and aqueous extracts of the aerial parts of $M$. peregrina exhibited antihyperglycemic activity against streptozotocin diabetic rats by lowering their blood glucose levels (El-Alfy et al., 2011). The hexane fraction from an ethanol extract of the plant reduced blood glucose levels by $64-77.44 \%$ for $3 \mathrm{~h}$ after $30 \mathrm{~min}$ of administration. The study suggested that this activity might be because the fraction contained the antihyperglycemic compounds lupeol acetate (62) and $\beta$ sitosterol (77). M. stenopetala leaf hydroalcoholic extract was reported to inhibit certain enzymes that related to hyperglycemia and hyperlipidia, such as maltase, sucrase, pancreatic cholesterol esterase, pancreatic lipase, and pancreatic $\alpha$-amylase (Toma et al., 2014). The leaf extract also reduced cholesterol, triglycerides, and the glucose lipid profile in fructose-induced rats (Geleta et al., 2016b).

Sangkitikomol et al. (2014) evaluated the effects of M. oleifera leaf hydroethanolic extract on advanced glycation end products. Throughout the study, the extract reduced the mRNA expression of PPAR $\alpha 1$, PPAR- $\gamma$, and HMG-CoAR that are responsible for maintaining lipid homeostasis. The extract inhibited the formation of AGE in HepG2 cells at doses of $2.5-10 \mathrm{mg} / \mathrm{mL}$. M. oleifera aqueous leaf extract also inhibited formation of both nonfluorescent and fluorescent advanced glycation end products by reducing monosaccharides, in addition to reducing the oxidation of thiols and protein carbonyl content (Nunthanawanich et al., 2016).

A study reported that an aqueous extract of $M$. oleifera leaves increased insulin levels and decreased insulin resistance, helping to combat hyperglycemia in diabetic rats (Tuorkey, 2016). The extract reduced creatinine and urea levels from damaged kidneys and increased the immune tolerance of the diabetic rats by increasing the activity of CD69, INF- $\gamma$, and CD44. Insulin-like protein was observed in the seed coat of M. oleifera (Paula et al., 2016). This protein had antigenic epitopes similar to insulin and displayed hypoglycemic activity on oral administration. The same activity was observed by a protein from $M$. oleifera leaves (Paula et al., 2017). The protein reduced blood glucose levels after single and repeated doses of the extract. It displayed antioxidant activity by increasing CAT levels and reducing MDA levels. It also cross-reacted with anti-insulin antibodies which proved that it might have antigenic epitopes similar to insulin. M. oleifera leaf extract reduced FPG level, post-prandial levels, blood glycated hemoglobin, total cholesterol, non-HDL-C, HDL-C, VLDL-C, and LDL-C in Type 2 diabetic patients (Kumari, 2010; Nambiar et al., 2010; Ghiridhari et al., 2011). Leaf powder capsules (4 g) significantly increased the secretion of insulin in healthy subjects (Anthanont et al., 2016).

M. oleifera seed extract reduced lipid peroxidation and increased antioxidant enzyme activity in streptozotocin-induced mice (Al-Malki and El Rabey, 2015). It also reduced the immunoglobin IgG and IgA activity of the mice which correlated to the reduction of IL- 6 that is responsible for glucose homeostasis and pancreatic beta cell activity. The seed extract normalized the activity of both damaged kidneys and pancreases without changing the pathology of the mice. It was reported that the bioactive compounds involved were quercetin (3), kaempferol (8), glucomoringin (30), and chlorogenic acid (54) and that they had various biological activities such as their anticancer, antioxidant, hypotensive, anti-inflammatory, hypoglycemic, and antidyslipidemic effects. Other than these compounds, isothiocyanates (34-37) had also been reported to show antidiabetic activity (Waterman et al., 2015). A study reported that benzylamine (108) isolated from M. oleifera reduced the plasma cholesterol, body weight gain, hyperglycemic responses, and fasting blood glucose levels of high fat dietinduced mice (Iffiu-Soltesz et al., 2010).

Barbagallo et al. (2016) reported that M. oleifera reduced IL6 expression and had protective effect toward adipocytes by inducing the expression of heme-oxygenase-1. The extract increased IRS-1 gene expression which is responsible for insulin resistance and a shortage of which causes type 2 diabetes. In addition, the extract also induced thermogenesis during the differentiation of adipose tissue by upregulating the activity of mediators of thermogenesis, specifically the uncoupling protein, $\operatorname{PPAR} \alpha$, sirtuin 1 , and coactivator $1 \alpha$. M. oleifera extract $(100 \mu \mathrm{g} / \mathrm{mL})$ showed the same behavior as $0.4 \mu \mathrm{g} / \mathrm{mL}$ pravastatin in inhibiting HMG-CoA reductase and decreasing cholesterol biosynthesis (Duangjai et al., 2011). M. oleifera also displayed synergistic effects with sitagliptin showing antihyperglycemic activity and delaying lenticular opacity in diabetic rats (Olurishe et al., 2016).

A different reaction of HDL level was observed between normal rabbits and hypercholesterolemic rabbits fed with $M$. oleifera. M. oleifera decreased HDL levels in normal rabbits but increased HDL levels in hypercholesterolemic rabbits (Mehta et al., 2003; Nunthanawanich et al., 2016). The lipid profiles of the aorta, heart, and liver were reduced in the hypercholesterolemic rabbits.

\section{Antifertility}

Mekonnen (2002) reported that an ethanolic extract of $M$. stenopetala leaves reduced fertility by $73.3 \%$. The extract exhibited oxytocic activity on guinea pig and mouse uteri. The extract also increased the smooth muscle of the mice uteri that might lead to contraction, thus rejecting implantation. M. concanensis stem bark also inhibited implantation by $46 \%$ using $400 \mathrm{mg} / \mathrm{kg}$ of the extract (Ravichandiran et al., 2007). The reaction was solvent-dependent. The ethyl acetate fraction showed the lowest anti-implantation activity in contrast to chloroform, petroleum ether, and an ethanol extract.

It was reported that $M$. oleifera leaf extract aborted $100 \%$ of implantation in seven rats (Sethi et al., 1988). The extract was administered after 5-10 days after mating. The aqueous root extract of the plant did not promote a favorable condition of the uterus for implantation of the fertilized eggs (Prakash et al., 1987). A high dose of the root extract, $600 \mathrm{mg} / \mathrm{kg}$, had anti-progestational activity, preventing the formation of the deciduoma in rats (Shukla et al., 1988). It also reduced the protein concentration for the formation of the uterus (Prakash et al., 1988). 


\section{Anti-inflammation}

A study reported that an ethanolic extract of the $M$. concanensis flower and fruit inhibited inflammation by 78.4 and $44.08 \%$, respectively (Rao et al., 2008; Jayabharathi and Chitra, 2011). An extract of the aerial part of $M$. peregrina decreased the effect of peritorial inflammation and reduced the permeability of small blood vessels (Elbatran et al., 2005). Ethanolic and aqueous extracts of $M$. peregrina seeds inhibited fresh egg albumininduced acute inflammation in rats at doses of $100-300 \mathrm{mg} / \mathrm{kg}$ p.o (Koheil et al., 2011).

The major anti-inflammation mechanism reported for $M$. oleifera was the inhibition of the NF-кB pathway. Four fractions of $M$. oleifera leaf (hexane, chloroform, ethyl acetate, and butanol) reduced IL-1 $\beta$, IL-6, PGE2, TNF- $\alpha$, and nitric oxide production in LPS macrophages (Arulselvan et al., 2016). Among the fractions, ethyl acetate possessed the strongest inhibition effects and was therefore further analyzed. The extract blocked the nuclear translocation of NF- $\kappa \mathrm{B}$ and increased inhibitor $\kappa \mathrm{B}$ expression, which was also observed in a fruit extract of $M$. oleifera. Higher concentrations (500 and 1,000 $\mu \mathrm{g} / \mathrm{mL}$ ), especially from chloroform fraction, were reported to be cytotoxic. Kooltheat et al. (2014) reported that an ethyl acetate extract of M. oleifera leaves suppressed the expression of RelA. A hydro ethanolic flower extract also reduced the activity of inflammatory mediators and proinflammatory cytokines such as PGE2, IL-6, IL- $1 \beta$, TNF- $\alpha$, NF- $\kappa$ B, iNOS, NO, and COX2 in LPS-induced RAW264.7 macrophages (Tan et al., 2015). In addition, the extract increased the activity of the anti-inflammatory cytokines IL-10 and $1 \kappa \mathrm{B}-\alpha$. Among the different parts of $M$. oleifera, the fruit showed the highest activity in reducing NO release induced by LPS in RAW264.7 cells (Lee et al., 2013).

Sashidara et al. (2009) isolated aurantiamide acetate (69) and 1,3-dibenzyl urea (74) from $M$. oleifera roots that exhibited inhibition toward IL-2 activity. Aurantiamide acetate (69) also inhibited TNF- $\alpha$ activity. 4-[( $\alpha-L-$ rhamnosyloxy)benzyl] isothiocyanate (34) and 4-[(4'-Oacetyl- $\alpha$-L-rhamnosyloxy)benzyl]isothiocyanate (37) from $M$. oleifera leaves displayed anti-inflammatory activity by regulating $\mathrm{IL}-1 \beta$ and iNOS expression in addition to reducing the production and expression of inflammatory markers in RAW macrophages (Waterman et al., 2014). 4-[( $\alpha$ - $L$-rhamnosyloxy)benzyl $]$ isothiocyanate (34) exhibited anti-inflammatory and antioxidant activity against cerebral tissue damage induced by cerebral ischemia reperfusion in rats (Galuppo et al., 2015b). The compound reduced iNOS, phospho-ERK p42/44, TNF- $\alpha$, MMP-9, p-selectin, and NFкBp65 nuclear translocation/IкB-alpha cytosolic degradation. A study also noted that 4 -[( $2^{\prime}-O$-acetyl- $\alpha-L$-rhamnosyloxy $)$ benzyl] isothiocyanate (35) suppressed COX-2 and iNOS activity in addition to inhibiting the expression of NO in RAW264.7 mouse macrophage cells induced by LPS (Park et al., 2011). The compound inhibited NF- $\kappa \mathrm{B}$ activation, the phosphorylation of ERK $1 / 2, I \kappa \mathrm{B} \alpha$ the phosphorylation of $\mathrm{IKK} \alpha / \beta$, and increase degradation of $I \kappa B \alpha$. The isothiocyanate showed stronger activity than other isothiocyanates such as benzyl isothiocyanate and sulforaphane. $\quad 4$-[( $\alpha$ - $L$-rhamnosyloxy $)$ benzyl $]$ isothiocyanate (34), 4 -[(2'-O-acetyl- $\alpha$ - $L$-rhamnosyloxy)benzyl $]$ isothiocyanate
(35), 4-[(3'-O-acetyl- $\alpha$ - $L$-rhamnosyloxy)benzyl $]$ isothiocyanate (36), and 4-[(4'-O-acetyl- $\alpha$ - $L$-rhamnosyloxy)benzyl $]$ isothiocyanate (37) inhibited the production of NO (Cheenpracha et al., 2010).

Galuppo et al. (2014) reported that 4-[( $\alpha$ - L-rhamnosyloxy) benzyl] isothiocyanate (34) exhibited anti-inflammatory activity toward multiple sclerosis cascades. The compound specifically reduced the imbalance of $\mathrm{Bax} / \mathrm{BCl}-2$ and inhibited TNF- $\alpha$ activity on myelin oligodendrocyte glycoprotein 35-55-induced C57B1/G male mice. The compound also inhibited GSK3 $\beta$ levels and normalized the Wnt- $\beta$-catenin pathway in experimental autoimmune encephalomyelitis mice (Giacoppo et al., 2016). The compound attenuated apoptosis in addition to suppressing PPAR $\gamma$ activation. 4-[( $\alpha$ - $L$-rhamnosyloxy) benzyl $]$ isothiocyanate (34), together with $\alpha$-cyclodextrin, inhibited the phosphorylation of p38 and Akt in LPS-induced inflammation in RAW 264.7 macrophage cells (Giacoppo et al., 2017). Another study reported that quercetin (3) and kaempferol (8) inhibited transcription 1(STAT-1) (Tan et al., 2015).

A study reported that a methanol extract of $M$. oleifera leaves reduced the edematogenic effect of carrageenan-induced and histamine-induced paw edema (Adedapo et al., 2015). The extract reduced the number of writhes of mice induced by acetic acid. The analgesic activity of the extract was recorded to be higher than that of the reference drug, indomethacin, at doses of 100 and $200 \mathrm{mg} / \mathrm{kg}$. The inflammatory response after administration of an $M$. oleifera ethanolic leaf extract was observed on atopic dermatitis mice and human keratinocytes (Choi et al., 2016). The extract reduced mannose receptor mRNA, retinoic acid-related orphan receptor $\gamma \mathrm{T}$, and thymic stromal lymphopoietin expression in ear tissue. From an in vitro assay, it was observed that the extract reduced mitogen-activated protein kinases, CCL17, IL- 6 pro-inflammatory cytokine-related mRNA, TNF- $\alpha$, and IL- $1 \beta$ expression. $M$. oleifera pod extract also inhibited the elevation of protein levels and mRNA of cyclooxygenease- 2 , TNF- $\alpha$, IL- 6 , and iNOS by inhibiting the phosphorylation of mitogen-activated protein kinases and $\kappa \mathrm{B}$ proteins (Muangnoi et al., 2012).

M. oleifera hydroethanolic and methanolic leaf extracts improved the cellular and humoral immunity of normal and immunosuppressed mice in a dose-dependent manner (Gupta et al., 2010; Nfambi et al., 2015). The extract increased the phagocytic index, weight of the thymus and spleen, antibody titer, and white blood cell and neutrophil concentration. An ethanolic extract of $M$. oleifera seeds inhibited the reaction of delayedtype hypersensitivity by reducing mean foot pad thickness on mice (Mahajan and Mehta, 2010). The immunosuppressive activity of the extract was observed by its ability to downregulate phagocytosis by macrophages. The ethanolic extract of the seeds also reduced white blood cell, and leukocyte concentration which usually leads to an immunity reaction. It increased paw edema which typically resulted in type IV hypersensitivity occurring. Methanolic extracts of $M$. oleifera leaves exhibited analgesic effects by reducing mechanical allodynia and thermal hyperalgesia in Freund's adjuvant arthritisinduced rats (Manaheji et al., 2011). In contrast, M. oleifera methanolic root extracts only reduced thermal hyperalgesia in the 
rats. The activity of the root and leaf extracts were comparable with indomethacin activity. In addition, a combination of root and leaf extracts showed higher reduction of thermal hyperalgesia in lower doses. An ethanol extract of $M$. oleifera leaves and its major compounds, quercetin-3-O-glucoside (18), kaempferol-3$O$-glucoside (21), and crypto chlorogenic acid (55), showed antiinflammatory activity, inhibiting the migration and chemotactic oxidation of polymorphonuclear leukocytes (Vongsak et al., 2013).

Moringa species also inhibited ulcers induced by non-steroidal anti-inflammatory drugs. M. oleifera extract reduced gastric lesions from acetylsalicylic acid, serotonin, and indomethacin (Pal et al., 1995), while an extract of the aerial part of $M$. peregrina reduced gastric lesions from indomethacin (Elbatran et al., 2005). A hydroalcoholic extract of M. oleifera seeds reduced the lesion severity and size of acute colitis induced by aceticacid in rats (Minaiyan et al., 2014). The extract also reduced the activity of TNF- $\alpha$, IL-4, IL- 6 , and myeloperoxide which are usually responsible for inflammatory bowel diseases. Debnath and Guha (2007) reported that an M. oleifera aqueous leaf extract reduced the mean ulcer index in addition to increasing 5HT concentration and enterochromaffin cell concentration. The extract protected against ulcer formation in aspirin-induced rats by stimulating enterochromaffin cells in the gastrointestinal tract via $5-\mathrm{HT}_{3}$ receptors (Debnath et al., 2011).

The ethyl acetate fraction of $M$. oleifera leaves obtained from a hydroethanolic extract of the plant increased normal human dermal fibroblast migration and cell proliferation (Gothai et al., 2016). It was observed that a higher dose, more than $125 \mu \mathrm{g} / \mathrm{mL}$, reduced cell proliferation. High concentrations of phenols in the extract might induced caspase and apoptosis. The migration observed also displayed a $9 \%$ better activity than the positive control, allantoin. The leaf ethyl acetate extract contained 4[( $2^{\prime}-O$-acetyl- $\alpha$ - $L$-rhamnosyloxy)benzyl] isothiocyanate (35) and 4 -[(3'-O-acetyl- $\alpha$ - $L$-rhamnosyloxy)benzyl $]$ isothiocyanate (36), both of which have anti-inflammatory activity. Muhammad et al. (2016) reported that a leaf extract of $M$. oleifera proliferated tissue cells, hence reducing the wound size of diabetic foot ulcers. It downregulated the activity of the inflammatory mediators TNF$\alpha$, IL- $1 \beta$, IL- 6 , iNOS, and COX-2. The extract also increased angiogenesis activity by reducing the time needed for the wound healing phase, in which vascular endothelial growth factor activity occurs. The study reported that the bioactive compound for this activity was vicenin-2 (17). An aqueous fraction of $M$. oleifera leaves reduced scar areas and increased the closure rates of wounds in addition to increasing the granuloma and skin breaking strength, granuloma dry weight, and hydroxyproline content of albino rats (Rathi et al., 2006). M. oleifera protease activity from leaf and root aqueous extracts exhibited proteolytic, fibrinolytic, and fibrinogenolytic activity on blood clotting (Satish et al., 2012). The protease showed similar activity to plasmin and thrombin. The protease also attenuated apoptosis in addition to suppressing PPAR gamma activation. Bhatnagar et al. (2013) reported that an M. oleifera seed extract, together with Acacia arabica biopolymers, had potential as a wound dressing material. In addition to being good antimicrobial substances, the biopolymers were biodegradable and could absorb water from 415 to $935 \%$. They also shortened the time taken to activate partial prothrombin and thromboplastin.

\section{Antihypertension}

Safaeian et al. (2015) showed that an M. peregrina leaf extract, administered before and during the administration of dexamethasone to rats, prevented their systolic blood pressure from increased but did not reduce already increased systolic blood pressure. The bioactive dose, $400 \mathrm{mg} / \mathrm{kg}$, showed low but significant antihypertensive activity. The compounds that were reported responsible for this activity were quercetin (3), apigenin (9), and lupeol (82) which had been previously reported to possess antihypertension activity. Safaeian et al. (2015) mentioned that the plants used were obtained during summer and this might affect the concentration of bioactive compounds in the plant. This correlated to a study that observed that the total phenolics in $M$. oleifera harvested in winter was higher than that in plants harvested in summer (Shih et al., 2011).

The vasodilatory activity of an $M$. stenopetala leaf crude extract and fraction were reported by Geleta et al. (2016a). The activity was observed in the thoracic aorta of guinea pigs that had been induced by various vascular contraction agents. Aqueous and 70\% ethanol crude extracts of the leaves reduced the vascular contraction induced by potassium chloride, methylene blue, epinephrine, and glibenclamide, in addition to inhibiting the increment of fructose-induced blood pressure in rats in a dose-dependent manner. The extract possessed alkaloids and glycosides that might have cause stronger activity than observed with the fractions. In the study, the extract had the greatest activity toward vascular contraction induced by potassium chloride either when the thoracic aorta was attached to the endothelium, or not. Geleta et al. (2016a) suggested that the extract blocked $\mathrm{Ca}^{2+}$ channels during this activity. The endothelium might have stimulated relaxing factors that increased the extract's activity.

A study reported that an ethanol extract of $M$. oleifera leaves reduced pulmonary arterial blood pressure immediately after administration of monocrotaline to rats (Chen et al., 2012). As pulmonary hypertension is usually related to increased reactive oxygen species in the system, the antioxidant activity of the extract that increased SOD activity might be the largest contribution toward its antihypertension activity on pulmonary hypertension. The bioactive compounds reported in this study were niazirin (97) and niaziridin (98). M. oleifera seeds also exhibited cardioprotective activity in spontaneous hypertensive rats (Randriamboavonjy et al., 2016). The extract increased cardiac diastolic function and reduced nocturnal heart rate without modifying the blood pressure of the rats. It also reduced fibrosis and the thickness of the left ventricular relative, interseptal, and anterior walls, in addition to reducing cardiac triglyceride levels. Plasmatic prostacyclin and PPAR- $\alpha$ and $\gamma$, activity was also increased by the extract. The study concluded that the extract exhibited antifibrotic and antihypertrophic activity that helped protect cardiac function in hypertension rats.

In addition, it was reported that the antioxidant activity of an M. oleifera leaf butanolic extract helped to reduce cardiac necrosis and oxidative stress in isoproterenol-induced rats (Panda, 2015). 
The extract reduced cardiac lipid peroxidation and increased cardiac antioxidants. The free radicals in the cardiac region were inhibited by the extract with $\mathrm{IC}_{50}$-values of $19.92 \pm 1.19 \mu \mathrm{g} / \mathrm{mL}$ which was comparable with quercetin (3) activity ( $\mathrm{IC}_{50}$-value of $19.95 \pm 1.17 \mu \mathrm{g} / \mathrm{mL}$ ). The extract also reduced inflammation and necrosis to almost normal myofibrillar structure. $N, \alpha-L$ rhamnopyranosyl vincosamide (67) exhibited cardioprotective activity by reducing the level of serum cardiac markers and myocardial necrosis in addition to normalizing the cardiac histology of isoproterenol-induced rats (Panda et al., 2013).

\section{Antispasmodic}

Hydro alcoholic extracts of $M$. peregrina leaves and seeds were investigated for their antispasmodic activity on ileum spasms (Sadraei et al., 2015). The leaves inhibited ileum spasms induced by potassium chlorine $\left(\mathrm{IC}_{50}: 439 \pm 108 \mu \mathrm{g} / \mathrm{mL}\right)$, electrical field stimulation $\left(\mathrm{IC}_{50}: 314 \pm 92 \mu \mathrm{g} / \mathrm{mL}\right.$ ), and acetylcholine $\left(\mathrm{IC}_{50}: 365\right.$ $\pm 61 \mu \mathrm{g} / \mathrm{mL}$ ). It was observed that the seed extract displayed better inhibition than the leaves against ileum spasms induced by potassium chloride ( $\mathrm{IC}_{50}: 87 \pm 18 \mu \mathrm{g} / \mathrm{mL}$ ), electrical field stimulation $\left(\mathrm{IC}_{50}: 230 \pm 51 \mu \mathrm{g} / \mathrm{mL}\right)$, and acetylcholine $\left(\mathrm{IC}_{50}\right.$ : $118 \pm 18 \mu \mathrm{g} / \mathrm{mL})$. The aqueous extract of $M$. oleifera seeds exhibited higher inhibition activity against acetylcholine-induced contractions ( $\mathrm{ED}_{50}$ of $65.6 \mathrm{mg} / \mathrm{mL}$ ) (Caceres et al., 1992).

\section{Others}

A study reported that $M$. oleifera exhibited antidepressant activity (Kaur et al., 2015). The crude extract showed positive results in the forced swim test, tail suspension test, and locomotor activity test. The activity was enhanced with coadministration of the SSRI depression drug, fluoxetine. In addition, high doses of the extract, particularly $2,000 \mathrm{mg} / \mathrm{kg}$, did not exert toxicity on the tested mice. Akanni et al. (2014) reported that an ethanol extract of $M$. oleifera leaves exhibited antileukemic activity against benzene-induced leukemic Wistar rats. The extract normalized the leukemic condition, increased $\mathrm{GSH}$, and reduced MDA levels in the rats. Galuppo et al. (2015a) reported that isothiocyanate, specifically $4-[(\alpha-L-$ rhamnosyloxy)-benzyl] isothiocyanate (34), isolated from $M$. oleifera delayed ALS development. The compound reduced PARP-1 activity in addition to promoting Nrf-2 activity. The study suggested that the isothiocyanate interfered with motor neuron degeneration and ALS development in the SOD1 rats. Upon administration of $125 \mathrm{mg} / \mathrm{kg}$ M. oleifera leaf extract, rats' antibody against the Salmonella typhimurium "O" antigen

\section{REFERENCES}

Abarikwu, S. O., Benjamin, S., Ebah, S. G., Obilor, G., and Agbam, G. (2017). Protective effect of Moringa oleifera oil against $\mathrm{HgCl}_{2}$-induced hepatoand nephro-toxicity in rats. J. Basic Clin. Physiol. Pharmacol. 28, 337-345. doi: 10.1515/jbcpp-2016-0033

Abd El Baky, H. H., and El-Baroty, G. S. (2013). Characterization of Egyptian Moringa peregrine seed oil and its bioactivities. Int. J. Manage. Sci. Bus. Res. 2, 98-108.

Abdel-Rahman Tahany, M. A., Hegazy, A. K., Mohsen Sayed, A., Kabiel, H. F., ElAlfy, T., and El-Komy, S. M. (2010). Study on combined antimicrobial activity increased to $50 \%$. The extract also increased the concentration of serum immunoglobulins, white blood cells, and neutrophils, hence increasing the humoral immune response of the rats (Jayanthi et al., 2015).

\section{TOXICITY}

Awodele et al. (2012) reported that an aqueous extract of $M$. oleifera leaves did not produce any mortality in Wistar albino mice at orally administered doses of up to $6,400 \mathrm{mg} / \mathrm{kg}$. Higher doses $(3,200$ and $6,400 \mathrm{mg} / \mathrm{kg})$ did triggered dullness and reduced locomotion in the rats. There was no significant difference observed on the rats' sperm quality, or on their hematological, histological, and biochemical parameters. The $\mathrm{LD}_{50}$-value was determined to be $1,585 \mathrm{mg} / \mathrm{kg}$. In another study, it was reported that high doses of $M$. oleifera leaves $(3,000 \mathrm{mg} / \mathrm{kg})$ caused the presence of micro nucleated polychromatic erythrocytes in the femur bone marrow of Sprague-Dawley rats (Asare et al., 2012). The study reported that doses of more than $3,000 \mathrm{mg} / \mathrm{kg}$ caused acute toxicity and increased the urea levels of the rats. The study reported that this was caused by high concentrations of nitrogenous compounds in the $M$. oleifera, potentially from proteins.

\section{CONCLUSION}

Various research has been conducted to evaluate the traditional uses of Moringa species and all of the research supported the traditional claims. However, there are still an abundance of traditional uses that have not been evaluated, especially in species other than M. oleifera and M. stenopetala. Hence, further research is needed to exploit the many uses of Moringa species.

\section{AUTHOR CONTRIBUTIONS}

NA obtained the literatures and wrote the manuscript while $\mathrm{KH}$ and EK gave ideas and edited the manuscript.

\section{ACKNOWLEDGMENTS}

The authors would like to thank the Ministry of Agriculture and Agro-based Industry (MOA) Malaysia, for the financial support under grant number NH1015D074. Moreover, we like to thank Universiti Kebangsaan Malaysia (UKM) for allowing us to use all its facilities. of some biologically active constituents from wild Moringa peregrina Forssk. J. Yeast Fungal Res. 1, 15-24.

Abe, R., and Ohtani, K. (2013). An ethnobotanical study of medicinal plants and traditional therapies on Batan Island, the Philippines. J. Ethnopharmacol. 2013, 554-565. doi: 10.1016/j.jep.2012. 11.029

Adedapo, A. A., Falayi, O. O., and Oyagbemi, A. A. (2015). Evaluation of the analgesic, anti-inflammatory, anti-oxidant, phytochemical and toxicological properties of the methanolic leaf extract of commercially processed Moringa oleifera in some laboratory animals. J. Basic Clin. Physiol. Pharmacol. 26, 491-499. doi: 10.1515/jbcpp-2014-0105 
Agrawal, N. D., Nirala, S. K., Shukla, S., and Mathur, R. (2015). Co-administration of adjuvants along with Moringa oleifera attenuates beryllium-induced oxidative stress and histopathological alterations in rats. Pharm. Biol. 53, 1465-1473. doi: 10.3109/13880209.2014.986685

Akanni, E. O., Adedeji, A. L., Adedosu, O. T., Olaniran, O. I., and Oloke, J. K. (2014). Chemopreventive and anti-leukemic effects of ethanol extracts of Moringa oleifera leaves on wistar rats bearing benzene induced leukemia. Curr. Pharm. Biotechnol. 15, 563-568. doi: 10.2174/1389201015666140717090755

Al-Asmari, A. K., Albalawi, S. M., Athar, M. T., Khan, A. Q., Al-Shahrani, H., and Islam, M. (2015). Moringa oleifera as an anti-cancer agent against breast and colorectal cancer cell lines. PLOS ONE 10:e0135814. doi: 10.1371/journal.pone. 0135814

Al-Malki, A. L., and El Rabey, H. A. (2015). The Antidiabetic effect of low doses of Moringa oleifera Lam. seeds on streptozotocin induced diabetes and diabetic nephropathy in male rats. BioMed. Res. Int. 2015, 1-13. doi: $10.1155 / 2015 / 381040$

Al-Owaisi, M., Al-Hadiwi, N., and Khan, S. A. (2014). GC-MS analysis, determination of total phenolics, flavonoids content and free radical scavenging activities of various crude extracts of Moringa peregrina (Forssk.) Fiori leaves. Asian Pac. J. Trop. Biomed. 4, 964-970. doi: 10.12980/APJTB.4.201414B295

Ananias, K. N. (2015). Antioxidant Activities, Phytochemical, and Micronutrients Analysis of African Moringa (Moringa ovalifolia). Master of Science, The University of Namibia.

Anthanont, P., Lumlerdkij, N., Akarasereenont, P., Vannasaeng, S., and Sriwijitkamol, A. (2016). Moringa oleifera leaf increases insulin secretion after single dose administration: a preliminary study in healthy subjects. J. Med. Assoc. Thai. 99, 308-313.

Anwar, F., Latif, S., Ashraf, M., and Gilani, A. H. (2007). A food plant with multiple medicinal uses. Phytother. Res. 21, 17-25. doi: 10.1002/ptr.2023

Arulselvan, P., Tan, W. S., Gothai, S., Muniandy, K., Fakurazi, S., Mohd Esa, N., et al. (2016). Anti-inflammatory potential of ethyl acetate fraction of Moringa oleifera in Downregulating the NF- $\mathrm{kB}$ signaling pathway in lipopolysaccharide-stimulated macrophage. Molecules 21, 1452-1465. doi: 10.3390/molecules 21111452

Asare, G. A., Gyan, B., Bugyei, K., Adjei, S., Mahama, R., Addo, P., et al. (2012). Toxicity potentials of the nutraceutical Moringa oleifera at supra-supplementation levels. J. Ethnopharmacol. 139, 265-272. doi: 10.1016/j.jep.2011.11.009

Atawodi, S. E., Atawodi, J. C., Idakwo, G. A., Pfundstein, B., Haubner, R., Wurtele, G., et al. (2010). Evaluation of the polyphenol content and antioxidant properties of methanol extracts of the leaves, stem, and root barks of Moringa oleifera Lam. J. Med. Food. 13, 710-716. doi: 10.1089/jmf.2009.0057

Awodele, O., Oreagba, I. A., Odoma, S., Texeira Da Silva, J. A., and Osunkalu, V. O. (2012). Toxicological evaluation of the aqueous leaf extract of Moringa oleifera Lam. J. Ethnopharmacol. 139, 330-336. doi: 10.1016/j.jep.2011.10.008

Ayyari, M., Salehi, P., Ebrahimi, S. N., Zimmermann, S., Portmann, L., Krauth-Siegel, R. L., et al. (2013). Antitrypanosomal isothiocyanate and thiocarbamate glycosides from Moringa peregrina. Planta Med. 80, 86-89. doi: $10.1055 / \mathrm{s}-0033-1351102$

Balamurugan, V., and Balakrishnan, V. (2013). Evaluation of phytochemical, pharmacognostical and antimicrobial activity from the bark of Moringa concanensis Nimmo. Int. J. Curr. Microbiol. Appl. Sci. 2, 117-125.

Barbagallo, I., Vanella, L., Distefano, A., Nicolosi, D., Maravigna, A., Lazzarino, G., et al. (2016). Moringa oleifera Lam. improves lipid metabolism during adipogenic differentiation of human stem cells. Eur. Rev. Med. Pharmacol. Sci. 20, 5223-5232.

Bargah, R. K., and Das, C. (2014). Isolation and characterization of steroidal glycoside from chloroform extract of the stem bark of Moringa pterygosperma Gaertn. Int. J. Innov. Res. Sci. Eng. Technol. 3, 18319-18322. doi: 10.15680/IJIRSET.2014.0312077

Bazrafshan, E., Mostafapour, F. K., Faridi, H., and Zazouli, M. A. (2012). Application of Moringa peregrina seed extract as a natural coagulant for phenol removal from aqueous solutions. Afr. J. Biotechnol. 11, 16758-16766. doi: $10.5897 / \mathrm{AJB} 12.1779$

Bekele, B., Adane, L., Tariku, Y., and Hailu, A. (2013). Evaluation of antileishmanial activities of triglycerides isolated from roots of Moringa stenopetala. Med. Chem. Res. 22, 4592-4599. doi: 10.1007/s00044-013-0467-x
Berkovich, L., Earon, G., Ron, I., Rimmon, A., Vexler, A., and Lev-Ari, S. (2013). Moringa oleifera aqueous lead extract down-regulates nuclear factor-kappaB and increases cytotoxic effect of chemotherapy in pancreatic cancer cells. BMC Complement. Altern. Med. 13, 212-218. doi: 10.1186/1472-6882-13-212

Bharali, R., Tabassum, J., and Azad, M. R. H. (2003). Chemomodulatory effect of Moringa oleifera, Lam, on hepatic carcinogen metabolising enzymes, antioxidant parameters and skin papillomagenesis in mice. Asian Pac. J. Cancer Prev. 4, 131-139.

Bhatnagar, M., Parwani, L., Sharma, V., Ganguli, J., and Bhatnagar, A. (2013). Hemostatic, antibacterial biopolymers from Acacia arabica (Lam.) Willd. and Moringa oleifera (Lam.) as potential wound dressing materials. Indian J. Exp. Biol. 51, 804-810.

Budda, S., Butryee, C., Tuntipopipat, S., Rungsipipat, A., Wangnaithum, S., Lee, J. S., et al. (2011). Suppressive effects of Moringa oleifera Lam Pod against mouse colon carcinogenesis induced by azoxymethane and dextran sodium sulfate. Asian Pac. J. Cancer Prev. 12, 3221-3228.

Caceres, A., Saravia, A., Rizzo, S., Zabala, L., De Leon, E., and Nave, F. (1992). Pharmacologic properties of Moringa oleifera. 2: screening for antispasmodic, antiinflammatory and diuretic activity. J. Ethnopharmacol. 36, 233-237. doi: 10.1016/0378-8741(92)90049-W

Cheenpracha, S., Park, E. J., Yoshida, W. Y., Barit, C., Wall, M., Pezzuto, J. M., et al. (2010). Potential anti-inflammatory phenolic glycosides from the medicinal plant Moringa oleifera fruits. Bioorg. Med. Chem. 18, 6598-6602. doi: 10.1016/j.bmc.2010.03.057

Chen, K. H., Chen, Y. J., Yang, C. H., Liu, K. W., Chang, J. L., Pan, S. F., et al. (2012). Attenuation of the extract from Moringa oleifera on monocrotaline-induced pulmonary hypertension in rats. Chin. J. Physiol. 55, 22-30. doi: 10.4077/CJP.2012.AMM104

Chitravadivu, C., Bhoopathi, M., Balakrishnan, V., Elavazhagan, T., and Jayakumar, S. (2009). Antimicrobial activity of laehiums prepared by herbal venders, South India. Amer. Eur. J. Sci. Res. 4, 142-147.

Choi, E. J., Debnath, T., Tang, Y., Ryu, Y. B., Moon, S. H., and Kim, E. K. (2016) Topical application of Moringa oleifera leaf extract ameliorates experimentally induced atopic dermatitis by the regulation of Th1/Th2/Th17 balance. Biomed. Pharmacother. 84, 870-877. doi: 10.1016/j.biopha.2016.09.085

Chuang, P. H., Lee, C. W., Chou, J. Y., Murugan, M., Shieh, B. J., and Chen, H. M. (2007). Anti-fungal activity of crude extracts and essential oil of Moringa oleifera Lam. Bioresour. Technol. 98, 232-236. doi: 10.1016/j.biortech.2005.11.003

Dalvand, A., Gholibegloo, E., Ganjali, M. R., Golchinpoor, N., Khazaei, M., Kamani, H., et al. (2016). Comparison of Moringa stenopetala seed extract as a clean coagulant with Alum and Moringa stenopetala-Alum hybrid coagulant to remove direct dye from textile wastewater. Environ. Sci. Pollut. Res. 23, 16396-16405. doi: 10.1007/s11356-016-6708-z

Das, B. R., Kurup, P. A., and Narasimha Rao, P. L. (1957). Antibiotic principle from Moringa pterygosperma. VII. Antibacterial activity and chemical structure of compounds related to pterygospermin. Indian J. Med. Res. 45, 191-196.

Debnath, S., Biswas, D., Ray, K., and Guha, D. (2011). Moringa oleifera induced potentiation of serotonin release by $5 \mathrm{HT} 3$ receptors in experimental ulcer model. Phytomedicine 18, 91-95. doi: 10.1016/j.phymed.2010.06.003

Debnath, S., and Guha, D. (2007). Role of Moringa oleifera on enterochromaffin cell count and serotonin content of experimental ulcer model. Indian J Exp Biol. 45, 726-731.

Dehshahri, S., Afsharypuor, S., Asghari, G., and Mohagheghzadeh, A. (2012a). Determination of volatile glucosinolate degradation products in seed coat, stem and in vitro cultures of Moringa peregrina (Forssk.) Fiori. Res. Pharm. Sci. 7 , $51-56$.

Dehshahri, S., Wink, M., Afsharypuor, S., Asghari, G., and Mohagheghzadeh, A. (2012b). Antioxidant activity of methanolic leaf extract of Moringa peregrina (Forssk.) Fiori. Res. Pharm. Sci. 7, 111-118.

Devaraj, V. C., Krishna, B. G., and Viswanatha, G. L. (2011). Simultaneous determination of quercetin, rutin and kaempferol in the leaf extracts of Moringa oleifera Lam. and Raphinus sativus Linn. by liquid chromatographytandem mass spectrometry. J. Chin. Integrat. Med. 9, 1022-1030. doi: $10.3736 /$ jcim 20110914

Diab, K. A., Guru, S. K., Bhushan, S., and Saxena, A. K. (2015). In vitro anticancer activities of Anogeissus latifolia, Terminalia bellerica, Acacia catechu and 
Moringa oleiferna Indian plants. Asian Pac. J. Cancer Prev. 16, 6423-6428. doi: 10.7314/APJCP.2015.16.15.6423

Duangjai, A., Ingkaninan, K., and Limpeanchob, N. (2011). Potential mechanisms of hypocholesterolaemic effect of Thai spices/dietary extracts. Nat. Prod. Res. 25, 341-352. doi: 10.1080/14786411003754249

Dzotam, J. K., Touani, F. K., and Kuete, V. (2016). Antibacterial and antibioticmodifying activities of three food plants (Xanthosoma mataffa Lam., Moringa oleifera (L.) Schott and Passiflora edulis Sims) against multidrug-resistant (MDR) Gram-negative bacteria. BMC Complement. Altern. Med. 16:9. doi: 10.1186/s12906-016-0990-7

Eilert, U., Wolters, B., and Nahrstedt, A. (2007). The antibiotic principle of seeds of Moringa oleifera and Moringa stenopetala. Planta Med. 42, 55-61. doi: 10.1055/s-2007-971546

El-Alfy, T. S., Ezzat, S. M., Hegazy, A. K., Amer, A. M. M., and Kamel, G. M. (2011). Isolation of biologically active constituents from Moringa peregrina (Forssk.) Fiori. (family: Moringaceae) growing in Egypt. Pharmacogn. Mag. 7, 109-115. doi: 10.4103/0973-1296.80667

El-Awady, M. A., Hassan, M. M., Abdel-Hameed, E. S., and Gaber, A. (2015). Comparison of the antimicrobial activities of the leaves-crude extracts of Moringa peregrina and Moringa oleifera in Saudi Arabia. Int. J. Curr. Microbiol. Appl. Sci. 4, 1-9.

Elbatran, S. A., Abdel-Salam, O. M., Abdelshfeek, K. A., Nazif, N. M., Ismail, S. I., and Hammouda, F. M. (2005). Phytochemical and pharmacological investigations on Moringa peregrina (Forssk). Nat. Product Sci. 11, 199-206.

Elgamily, H., Moussa, A., Elboraey, A., El-Sayed, H., Al-Moghazy, M., and Abdalla, A. (2016). Microbiological assessment of Moringa oleifera extracts and its incorporation in novel dental remedies against some oral pathogens. Open Access Maced. J. Med. Sci. 4, 585-590. doi: 10.3889/oamjms.2016.132

El-Haddad, A. E., Koheil, M. A., Abd El-Khalik, S. M., Mohamed El-Hefnawy, H., Al-Azzouni, A. S., and Osman, S. (2002). "Antihyperglycemic activity and nitrile glycosides of Moringa Peregrina (Forssk.) seeds," in Fourth EuroMediterranean conference of Natural Products and Drug Discovery: Back to Mother Nature (BioNat-IV) (Sharm El-Sheikh).

Elsayed, E. A., Sharaf-Eldin, M. A., and Wadaan, M. (2015). In vitro evaluation of cytotoxic activities of essential oil from Moringa oleifera seeds on HeLa, HepG2, MCF-7, CACO-2 and L929 cell lines. Asian Pac. J. Cancer Prev. 16, 4671-4675. doi: 10.7314/APJCP.2015.16.11.4671

Eyarefe, O. D., Idowu, A., and Afolabi, J. M. (2015). Healing potentials of oral Moringa oleifera leaves extract and tetracycline on methicillin resistant Staphylococcus aureus infected wounds of Wistar rats. Niger. J. Physiol. Sci. 30, 73-78.

Fahey, W. J. (2005). Moringa oleifera: a review of the medical evidence for its nutritional, therapeutic, and prophylactic properties. Part 1. Trees Life J. 1, 1-24.

Faizi, S., Siddiqui, B. S., Saleem, R., Siddiqui, S., and Aftab, K. (1994). Isolation and structure elucidation of new nitrile and mustard oil glycosides from Moringa oleifera and their effect on blood pressure. J. Nat. Prod. 57, 1256-1261. doi: 10.1021/np50111a011

Faizi, S., Sumbul, S., Versiani, M. A., Saleem, R., Sana, A., and Siddiqui, H. (2014). GC/GCMS analysis of the petroleum ether and dichloromethane extract of Moringa oleifera roots. Asian Pac. J. Trop. Biomed. 4, 650-654. doi: 10.12980/APJTB.4.201414B141

Fakurazi, S., Hairuszah, I., and Nanthini, U. (2008). Moringa oleifera Lam prevents acetaminophen induced liver injury through restoration of glutathione level. Food Chem. Toxicol. 46, 2611-2615. doi: 10.1016/j.fct.2008.04.018

Forest Department (2016). Medicinal Plants of Sindh: Swanjehro. Government of Sindh.

Gaikwad, M., Kale, S., Bhandare, S., Urunkar, V., and Rajmane, A. (2011). Extraction, characterization and comparison of fixed oil of Moringa oleifera $\mathrm{L}$ \& Moringa concanensis Nimmo Fam. Moringaceae. Int. J. PharmTech Res. 3, $1567-1575$.

Galuppo, M., De Nicola, G. R., Iori, R., Dell'utri, P., Bramanti, P., and Mazzon, E. (2013). Antibacterial activity of glucomoringin bioactivated with myrosinase against two important pathogens affecting the health of long-term patients in hospitals. Molecules 18, 14340-14348. doi: 10.3390/molecules 181114340

Galuppo, M., Giacoppo, S., De Nicola, G. R., Iori, R., Navarra, M., Lombardo, G. E., et al. (2014). Antiinflammatory activity of glucomoringin isothiocyanate in a mouse model of experimental autoimmune encephalomyelitis. Fitoterapia 95, 160-174. doi: 10.1016/j.fitote.2014.03.018
Galuppo, M., Giacoppo, S., Iori, R., De Nicola, G. R., Bramanti, P., and Mazzon, E. (2015a). Administration of 4-(alpha-L-rhamnosyloxy)-benzyl isothiocyanate delays disease phenotype in SOD1G93A rats: a transgenic model of amyotrophic lateral sclerosis. Biomed. Res. Int. 1-12. doi: 10.1155/2015/259417

Galuppo, M., Giacoppo, S., Iori, R., De Nicola, G. R., Milardi, D., Bramanti, P., et al. (2015b). 4( $\alpha$-L-rhamnosyloxy)-benzyl isothiocyanate, a bioactive phytochemical that defends cerebral tissue and prevents severe damage induced by focal ischemia/reperfusion. J. Biol. Regul. Homeost. Agents. 29, 343-356.

Geleta, B., Makonnen, E., Debella, A., Abebe, A., and Fekadu, N. (2016a). In vitro vasodilatory activity and possible mechanisms of the crude extracts and fractions of Moringa stenopetala (Baker f.) Cufod. leaves in isolated thoracic aorta of guinea pigs. J. Exp. Pharmacol. 8, 35-42. doi: 10.2147/JEP.S117545

Geleta, B., Makonnen, E., Debella, A., and Tadele, A. (2016b). In vivo antihypertensive and antihyperlipidemic effects of the crude extracts and fractions of Moringa stenopetala (Baker f.) Cufod. Leaves in rats. Front. Pharmacol. 7:97. doi: 10.3389/fphar.2016.00097

Ghiridhari, V. V. A., Malhati, D., and Geetha, K. (2011). Anti-diabetic properties of drumstick (Moringa oleifera) leaf tablets. Int. J. Health Nutr. 2, 1-5.

Giacoppo, S., Rajan, T. S., De Nicola, G. R., Iori, R., Bramanti, P., and Mazzon, E. (2016). Moringin activates Wnt canonical pathway by inhibiting gsK3 $\beta$ in a mouse model of experimental autoimmune encephalomyelitis. Drug Des. Dev. Ther. 10, 3291-3304. doi: 10.2147/DDDT.S110514

Giacoppo, S., Rajan, T. S., Iori, R., Rollin, P., Bramanti, P., and Mazzon, E. (2017). The $\alpha$-cyclodextrin complex of the Moringa isothiocyanate suppresses lipopolysaccharideinduced inflammation in RAW 264.7 macrophage cells through Akt and p38 inhibition. Inflamm. Res. 66, 487-503. doi: 10.1007/s00011-017-1033-7

Gismondi, A., Canuti, L., Impei, S., Marco, G. D., Kenzo, M., Colizzi, V., et al. (2013). Antioxidant extracts of African medicinal plants induce cell cycle arrest and differentiation in B16F10 melanoma cells. Int. J. Oncol. 43, 956-964. doi: 10.3892/ijo.2013.2001

Gothai, S., Arulselvan, P., Tan, W. S., and Fakurazi, S. (2016). Wound healing properties of ethyl acetate fraction of Moringa oleifera in normal human dermal fibroblasts. J. Int. Ethnopharmacol. 5, 1-6. doi: 10.5455/jice.20160201055629

Guevara, A. P., Vargas, C., Sakurai, H., Fujiwara, Y., Hashimoto, K., Maoka, T., et al. (1999). An antitumor promoter from Moringa oleifera Lam. Mutat. Res. 440, 181-188. doi: 10.1016/S1383-5718(99)00025-X

Gupta, A., Gautam, M. K., Singh, R. K., Kumar, M. V., Rao, C. V., Goel, R. K., et al. (2010). Immunomodulatory effect of Moringa oleifera Lam. extract on cyclophosphamide induced toxicity in mice. Indian J. Exp. Biol. 48, 1157-1160.

Gupta, R., Dubey, D. K., Kannan, G. M., and Flora, S. J. (2007). Concomitant administration of Moringa oleifera seed powder in the remediation of arsenic-induced oxidative stress in mouse. Cell Biol. Int. 31, 44-56. doi: 10.1016/j.cellbi.2006.09.007

Habtemariam, S. (2016). The African Moringa is to change the lives of millions in Ethiopia and far beyond. Asian Pac. J. Trop. Biomed. 6, 355-356. doi: 10.1016/j.apjtb.2015.12.016

Habtemariam, S., and Varghese, G. K. (2015). Extractability of rutin in herbal tea preparations of Moringa stenopetala leaves. Beverages 1, 169-182. doi: 10.3390/beverages1030169

Ibrahim, M. A., Mohammed, A., Isah, M. B., and Aliyu, A. B. (2014). Antitrypanosomal activity of African medicinal plants: a review update. $J$. Ethnopharmacol. 154, 26-54. doi: 10.1016/j.jep.2014.04.012

Iffiu-Soltesz, Z., Wanecq, E., Lomba, A., Portillo, M. P., Pellati, F., Szoko, E., et al. (2010). Chronic benzylamine administration in the drinking water improves glucose tolerance, reduces body weight gain and circulating cholesterol in high-fat diet-fed mice. Pharmacol. Res. 61, 355-363. doi: 10.1016/j.phrs.2009. 12.014

Jayabharathi, M., and Chitra, M. (2011). Evaluation of anti-inflammatory, analgesic and antipyretic activity of Moringa concanensis Nimmo. J. Chem. Pharm. Res. 3, 802-806.

Jayanthi, M., Garg, S. K., Yadav, P., Bhatia, A. K., and Goel, A. (2015). Some newer marker phytoconstituents in methanolic extract of Moringa oleifera leaves and evaluation of its immunomodulatory and splenocytes proliferation potential in rats. Indian J. Pharmacol. 47, 518-523. doi: 10.4103/0253-7613.165199

Joy, A. E., Kunhikatta, S. B., and Manikkoth, S. (2013). Anti-convulsant activity of ethanolic extract of Moringa concanensis leaves in Swiss albino mice. Arch. Med. Health Sci. 1, 6-9. doi: 10.4103/2321-4848.113548 
Jung, I. L. (2014). Soluble extract from Moringa oleifera leaves with a new anticancer activity. PLoS ONE 9:e95492. doi: 10.1371/journal.pone.0095492

Jung, I. L., Lee, J. H., and Kang, S. C. (2015). A potential oral anticancer drug candidate, Moringa oleifera leaf extract, induces the apoptosis of human hepatocellular carcinoma cells. Oncol. Lett. 10, 1597-1604. doi: 10.3892/ol.2015.3482

Karmegam, N., and Nagaraj, R. (2017). "Combinatorial antibacterial activity of selective medicinal plant species from Southern Eastern Ghats," in National Seminar on Recent Advances in Biotechnology and Applied Microbiology (Salem).

Kasolo, J. N., Bimenya, G. S., Ojok, L., Ochieng, J., and Ogwal-Okeng, J. W. (2010). Phytochemicals and uses of Moringa oleifera leaves in Ugandan rural communities. J. Med. Plant Res. 4, 753-757. doi: 10.5897/JMPR10.492

Kaur, A., Kaur, P. K., Singh, S., and Singh, I. P. (2014). Antileishmanial compounds from Moringa oleifera Lam. Z Naturforsch C. 69, 110-116. doi: 10.5560/znc.2013-0159

Kaur, G., Invally, M., Sanzagiri, R., and Buttar, H. S. (2015). Evaluation of the antidepressant activity of Moringa oleifera alone and in combination with fluoxetine. J. Ayurveda Integr. Med. 6, 273-279. doi: 10.4103/0975-9476. 172384

Kifleyohannes, T., Terefe, G., Tolossa, Y. H., Gliday, M., and Kebede, N. (2014). Effect of crude extracts of Moringa stenopetala and Artemisia absinthium on parasitaemia of mice infected with Trypanosoma congolense. BMC Complement. Altern. Med. 7:390. doi: 10.1186/1756-0500-7-390

Kleiman, R., Ashley, D. A., and Brown, J. H. (2008). Comparison of two seed oils used in cosmetics, moringa and marula. Ind. Crops Prod. 28, 361-364. doi: $10.1016 /$ j.indcrop.2008.04.003

Koheil, M. A., Hussein, M. A., Othman, S. M., and El-Haddad, A. (2011). Antiinflammatory and antioxidant activities of Moringa peregrina seeds. Free Radic. Antioxid. 1, 49-61. doi: 10.5530/ax.2011.2.10

Kooltheat, N., Sranujit, R. P., Chumark, P., Potup, P., Laytragoon-Lewin, N., and Usuwanthim, K. (2014). An ethyl acetate fraction of Moringa oleifera Lam. inhibits human macrophage cytokine production induced by cigarette smoke. Nutrients 6, 697-710. doi: 10.3390/nu6020697

Kumari, D. J. (2010). Hypoglycemic effect of Moringa oleifera and Azadirachta indica in type-2 diabete. Bioscan. 5, 211-214.

Kurmi, R., Ganeshpurkar, A., Bansal, D., Agnihotri, A., and Dubey, N. (2014). Ethanol extract of Moringa oleifera prevents in vitro glucose induced cataract on isolated goat eye lens. Indian J. Ophthalmol. 62, 154-157. doi: 10.4103/0301-4738.116482

Kurokawa, M., Wadhwani, A., Kai, H., Hidaka, M., Yoshida, H., Sugita, C., et al. (2016). Activation of cellular immunity in herpes simplex virus type 1-infected mice by the oral administration of aquoeus extract of Moringa oleifera Lam. leaves. Phytother Res. 30, 797-804. doi: 10.1002/ptr.5580

Lalas, S., Gortzi, O., Athanasiadis, V., Tsaknis, J., and Chinou, I. (2012). Determination of Antimicrobial activity and resistance to oxidation of Moringa peregrina seed oil. Molecules 17, 2330-2334. doi: 10.3390/molecules17032330

Lalas, S., and Tsaknis, J. (2002). Extraction and identification of natural antioxidant from the seeds of the Moringa oleifera tree variety of Malawi. J. Amer. Oil Chem. Soc. 79, 677-683. doi: 10.1007/s11746-002-0542-2

Lee, H. J., Jeong, Y. J., Lee, T. S., Park, Y. Y., Chae, W. G., Chung, I. K., et al. (2013). Moringa fruit inhibits LPS induced NO/iNOS expression through suppressing the NFkB activation in RAW264.7 cells. Am. J. Chin. Med. 41, 1109-1123. doi: 10.1142/S0192415X13500754

Leone, A., Fiorillo, G., Criscuoli, F., Ravasenghi, S., Santagostini, L., Fico, G., et al. (2015a). Nutritional characterization of phenolic profiling of Moringa oleifera leaves grown in Chad, Sahrawi refugee camps, and Haiti. Int. J. Mol. Sci. 15, 18923-18937. doi: 10.3390/ijms160818923

Leone, A., Spada, A., Battezzati, A., Schiraldi, A., Aristil, J., and Bertoli, S. (2015b). Cultivation, genetic, ethnopharmacology, phytochemistry and pharmacology of Moringa oleifera leaves: an overview. Int. J. Mol. Sci. 16, 12791-12835. doi: 10.3390/ijms160612791

Lipipun, V., Kurokawa, M., Suttisri, R., Taweechotipatr, P., Pramyothin, P., Hattori, M., et al. (2003). Efficacy of Thai medicinal plant extracts against herpes simplex virus type 1 infection in vitro and in vivo. Antiviral Res. 60, 175-180. doi: 10.1016/S0166-3542(03)00152-9

Lurling, M., and Beekman, W. (2010). Anti-cyanobacterial activity of Moringa oleifera seeds. J. Appl. Phycol. 22, 503-510. doi: 10.1007/s10811-009-9485-y
Madi, N., Dany, M., Abdoun, S., and Usta, J. (2016). Moringa oleifera's nutritious aqueous leaf extract has anticancerous effects by compromising mitochondrial viability an ROS-dependent manner. J. Am. Coll. Nutr. 35, 604-613. doi: 10.1080/07315724.2015.1080128

Mahajan, G. S., and Mehta, A. A. (2010). Immunosuppressive activity of ethanolic extract of seeds of Moringa oleifera Lam. in experimental immune inflammation. J. Ethnopharmacol. 130, 183-186. doi: 10.1016/j.jep.2010.04.024

Mahmood, K. T., Mugal, T., and Haq, I. U. (2010). Moringa oleifera: a natural gift - a review. J. Pharm. Sci Res. 2, 775-781.

Maiyo, F. C., Moodley, R., and Singh, M. (2016). Cytotoxicity, antioxidant and apoptosis studies of quercetin-3-O-glucoside and 4-(beta-Dglucopyranosyl-1->4-alpha-L-rhamnopyranosyloxy)-benzyl isothiocyanate from Moringa oleifera. Anticancer. Agents Med. Chem. 16, 648-656. doi: $10.2174 / 1871520615666151002110424$

Manaheji, H., Jafari, S., Zaringhalam, J., Rezazadeh, S., and Taghizadfarid, R. (2011). Analgesic effects of methanolic extracts of the leaf or root of Moringa oleifera on complete Freund's adjuvant-induced arthritis in rats. J. Chin. Integrat. Med. 9, 216-222. doi: 10.3736/jcim20110216

Manguro, L. O., and Lemmen, P. (2007). Phenolics of Moringa oleifera leaves. Nat. Prod. Res. 21, 56-68. doi: 10.1080/14786410601035811

Marrufo, T., Nazzaro, F., Mancini, E., Fratianni, F., Coppola, R., De Martino, L., et al. (2013). Chemical composition and biological activity of the essential oil from leaves of Moringa oleifera Lam. cultivated in Mozambique. Molecules 18, 10989-11000. doi: 10.3390/molecules180910989

Marwah, R. G., Fatope, M. O., Al-Mahrooqi, R., Varma, G. B., Al Abadi, H., and Al-Burtamani, S. S. (2007). Antioxidant capacity of some edible and wound healing plants in Oman. Food Chem. 101, 465-470. doi: 10.1016/j.foodchem.2006.02.001

Mathur, B. S. (2005). Moringa Book. St. Louis, MI Trees for Life International.

Mehta, K., Balaraman, R., Amin, A. H., Bafna, P. A., and Gulati, O. D. (2003). Effect of fruits of Moringa oleifera on the lipid profile of normal and hypercholesterolaemic rabbits. J. Ethnopharmacol. 86, 191-195. doi: 10.1016/S0378-8741(03)00075-8

Mekonen, A., and Gebreyesus, T. (2000). Chemical investigation of the leaves of Moringa stenopetala. Bull. Chem. Soc. Ethiop. 14, 51-55. doi: 10.4314/bcse.v14i1.72018

Mekonnen, N., Houghton, P., and Timbrell, J. (2005). The toxicity of extracts of plant parts of Moringa stenopetala cells in vitro. Phytother. Res. 19, 870-875. doi: $10.1002 /$ ptr.1720

Mekonnen, Y. (2002). The Multi-purpose Moringa Tree: Ethiopia. Addis Ababa: Institute of Pathobiology; Addis Ababa University.

Mekonnen, Y., and Drager, B. (2003). Glucosinolates in Moringa stenopetala. Planta Med. 69, 380-382. doi: 10.1055/s-2003-38881

Mekonnen, Y., and Gessesse, A. (1998). Documentation on the uses of Moringa Stenopetala and its possible antileishmanial and antifertility effects. Ethiop. J. Sci. 21, 287-295. doi: 10.4314/sinet.v21i2.18126

Mekonnen, Y., Yardley, V., Rock, P., and Croft, S. (1999). In vitro antitrypanosomal activity of Moringa stenopetala leaves and roots. Phytother Res. 13, 538-539. doi: 10.1002/(SICI)1099-1573(199909)13:6<538::AID-PTR486>3.0.CO;2-K

Memon, G. M., Memon, S. A., and Memon, A. R. (1985). Isolation and structure elucidation of moringyne - a new glycoside from seeds of Moringa oleifera Lam. Pak. J. Sci. Ind. Res. 28, 7-9.

Miller, A. G., Morris, M., and Sruart-Smith, S. (1988). Plants of Dhofa: The Southern Region of Oman-Traditional, Economic and Medicinal Uses. Edinburgh, UK: Office of the Adviser for Conservation of the Environment, Diwan of Royal Court, Sultanate of Oman.

Minaiyan, M., Asghari, G., Taheri, D., Saeidi, M., and Nasr-Esfahani, S. (2014). Anti-inflammatory effect of Moringa oleifera Lam. seeds on acetic-induced acute colitis in rats. Avicenna J. Phytomed. 4, 127-136.

Monera, G. T., and Maponga, C. C. (2010). Moringa oleifera supplementation by patients on antiretroviral therapy. J. Int. AIDS Soc. 13:188. doi: 10.1186/1758-2652-13-S4-P188

Monera, T. G., Wolfe, A. R., Maponga, C. C., Benet, L. Z., and Guglielmo, J. (2008). Moringa oleifera leaf extracts inhibit $6 \beta$-hydroxylation of testosterone by CYP3A4. J. Infect. Dev. Ctries. 2, 379-383. doi: 10.3855/jidc.201

Muangnoi, C., Chingsuwanrote, P., Praengamthanachoti, P., Svasti, S., and Tuntipopipat, S. (2012). Moringa oleifera pod inhibits inflammatory mediator production by lipopolysaccharidestimulated RAW 264.7 murine 
macrophage cell lines. Inflammation 35, 445-455. doi: 10.1007/s10753-0119334-4

Muhammad, A. A., Arulselvan, P., Cheah, P. S., Abas, F., and Fakurazi, S. (2016). Evaluation of wound healing properties of bioactive aqueous fraction from Moringa oleifera Lam on experimentally induced diabetic animal model. Drug Des. Devel. Ther. 10, 1715-1730. doi: 10.2147/DDDT.S96968

Murakami, A., Kitazono, Y., Jiwajinda, S., Koshimizu, K., and Ohigashi, H. (1998). Niaziminin, a thiocarbamate from the leaves of Moringa oleifera, holds a strict structural requirement for inhibition of tumor-promoter-induced Epstein-Barr Virus activation. Planta Med. 64, 319-323. doi: 10.1055/s-2006-957442

Nadeem, M., and Imran, M. (2016). Promising features of Moringa oleifera oil: recent updates and perspectives. Lipids Health Dis. 15:212. doi: 10.1186/s12944-016-0379-0

Nambiar, V. S., Guin, P., Parnami, S., and Daniel, M. (2010). Impact of antioxidants from drumstick leaves on the lipid profile of hyperlipidemics. J. Herb. Med. Toxicol. 4, 165-172.

Ndhlala, A. R., Mulaudzi, R., Ncube, B., Abdelgadir, H. A., Plooy, C. P., and Staden, J. V. (2014). Antioxidant, antimicrobial and phytochemical variations in thirteen Moringa oleifera Lam. cultivars. Molecules 19, 10480-10494. doi: $10.3390 /$ molecules 190710480

Nfambi, J., Bbosa, G. S., Sembajwe, L. F., Gakunga, J., and Kasolo, J. N. (2015). Immunomodulatory activity of methanolic leaf extract of Moringa oleifera in Wistar albino rats. J. Basic Clin. Physiol. Pharmacol. 26, 603-611. doi: 10.1515/jbcpp-2014-0104

Ngamukote, S., Khannongpho, T., Siriwatanapaiboon, M., Sirikwanpong, S., Dahlan, W., and Adisakwattana, S. (2016). Moringa Oleifera leaf extract increases plasma antioxidant status associated with reduced plasma malondialdehyde concentration without hypoglycemia in fasting healthy volunteers. Chin. J. Integr. Med. doi: 10.1007/s11655-016-2515-0. [Epub ahead of print].

Nibret, E., and Wink, M. (2010). Trypanocidal and antileukaemic effects of the essential oils of Hagenia abyssinica, Leonotis ocymifolia, Moringa stenopetala, and their main individual constituents. Phytomedicine 17, 911-920. doi: 10.1016/j.phymed.2010.02.009

Nikkon, F., Saud, Z. A., Rahman, M. H., and Haque, M. E. (2003). In vitro antimicrobial activity of the compound isolated from chloroform extract of Moringa oleifera Lam. Pak. J. Biol. Sci. 6, 1888-1890. doi: 10.3923/pjbs.2003.1888.1890

Nunthanawanich, P., Sompong, W., Sirikwanpong, S., Makynen, K., Adisakwattana, S., Dahlan, W., et al. (2016). Moringa oleifera aquoeus leaf extract inhibits reducing monosaccharide-induced protein glycation and oxidation of bovine serum albumin. Springerplus 5:1098. doi: $10.1186 /$ s40064-016-2759-3

Nwosu, M. O., and Okafor, J. L. (1995). Preliminary studies of antifungal activities of some medicinal planst against Basidiobolus and some other pathogenic fungi. Mycoses 38, 191-195. doi: 10.1111/j.1439-0507.1995.tb00048.x

Odee, D. W., Muluvi, G. M., Machua, J., Olson, M. E., and Changwony, M. (2002). "Domestication of Moringa species in Kenya," in Development potential for Moringa products. Workshop (Dar es Salaam).

Ogunbino, A. O., Flamini, G., Cioni, P. L., Adebayo, M. A., and Oguwande, I. A. (2009). Constituents of Cajanus cajan (L.) Millsp., Moringa oleifera Lam., Heliotropium indicum L. and Bidens pilosa L. from Nigeria. Nat. Prod. Commun. 4, 573-578.

Olson, M. E. (1999). The Home Page of the Plant Family Moringaceae [Online]. Available online at: http://www.mobot.org/gradstudents/olson/moringahome. html (Accessed, November 11, 2016).

Olson, M. E., and Razafimmandimbison, S. G. (2000). Moringa hildebrandtii (Moringaceae): a tree extinct in the wild but preserved by indigenous horticultural practices in Madagascar. Adansonia ser. 3. 22, 217-221.

Olson, M. E., and Rosell, J. A. (2006). Using heterochrony to detect modularity in the evolution of stem diversity in the plant family Moringaceae. Evolution 60, 724-734. doi: 10.1111/j.0014-3820.2006.tb01151.x

Olurishe, C., Kwanashie, H., Zezi, A., Danjuma, N., and Mohammed, B. (2016). Chronic administration of ethanol leaf extract of Moringa oleifera Lam. (Moringaceae) may compromise glycaemic efficacy of Sitagliptin with no significant effect in retinopathy in a diabetic rat model. J. Ethnopharmacol. 194, 895-903. doi: 10.1016/j.jep.2016.10.065
Padla, E. P., Solis, L. T., Levida, R. M., Shen, C. C., and Ragasa, C. Y. (2012). Antimicrobial isothiocyanates from the seeds of Moringa oleifera Lam. Z. Naturforsch. C. 67, 557-564. doi: 10.5560/ZNC.2012.67c0557

Pal, S. K., Mukherjee, P. K., and Saha, B. P. (1995). Studies on the antiulcer activity of Moringa oleifera leaf extract on gastric ulcer models in rats. Phytother. Res. 9, 463-465. doi: 10.1002/ptr.2650090618

Panda, S. (2015). Butanolic fraction of Moringa oleifera Lam. (Moringaceae) attenuates isoprotrenol-induced cardiac necrosis and oxidative stress in rats: an EPR study. EXCLI J. 14, 64-74. doi: 10.17179/excli2014-431

Panda, S., Kar, A., Sharma, P., and Sharma, A. (2013). Cardioprotective potential of $\mathrm{N}, \alpha$-L-rhamnopyranosyl vincosamide, an indole alkaloid, isolated from the leaves of Moringa oleifera in isoproterenol induced cardiotoxic rats: in vivo and in vitro studies. Bioorg. Med. Chem. 23, 959-962. doi: 10.1016/j.bmcl.2012.12.060

Park, E. J., Cheenpracha, S., Chang, C. L., Kondratyuk, P. T., and Pezzuto, M. J. (2011). Inhibition of lipopolysaccharide-induced cyclooxygenase2 expression and inducible nitric oxide synthase by 4 -[( $2^{\prime}$-oacetyl- $\alpha-\mathrm{L}-$ rhamnosyloxy)benzyl]isothiocyanate from Moringa oleifera. Nutr. Cancer. 63, 971-982. doi: 10.1080/01635581.2011.589960

Parrotta, J. A. (1993). Moringaceae Horseradish-Tree Family. U. S. G. P. OFFICE.

Patel, N., Patel, P., Patel, D., Desai, S., and Meshram, D. (2014). Phytochemical analysis and antibacterial activity of Moringa oleifera. Int. J. Med. Pharmaceut. Sci. 4, 27-34.

Patil, M. V., and Patil, D. A. (2005). Ethnomedicinal practises of Nasik District, Maharashta. Indian J. Tradit. Knowledge. 4, 287-290.

Paula, P. C., Oliveira, J. T., Sousa, D. O., Alves, B. G., Carvalho, A. F., Franco, O. L., et al. (2016). Insulin-like plant proteins as potential innovative drugs to treat diabetes-The Moringa oleifera case study. N. Biotechnol. 39, 99-109. doi: 10.1016/j.nbt.2016.10.005

Paula, P. C., Sousa, D. O., Oliveira, J. T., Carvalho, A. F., Alves, B. G., Pereira, M. L., et al. (2017). A protein isolate from Moringa oleifera leaves has hypoglycemic and antioxidant effects in alloxan-induced diabetic mice. Molecules 22, 1-15. doi: $10.3390 /$ molecules 22020271

Peixoto, J. R., Silva, G. C., Costa, R. A., De Sousa Fontanelle, J. R., Viera, G. H., Filho, A. A., et al. (2011). In vitro antibacterial effect of aqueous and ethanolic Moringa leaf extracts. Asian Pac. J. Trop. Med. 4, 201-204. doi: 10.1016/S1995-7645(11)60069-2

Popoola, J. O., and Obembe, O. O. (2013). Local knowledge, use pattern and geographical distribution of Moringa oleifera Lam. (Moringaceae) in Nigeria. J. Ethnopharmacol. 150, 682-691. doi: 10.1016/j.jep.2013.09.043

Prakash, A. O., Pathak, S., Shukla, S., and Mathur, R. (1987). Uterine histoarchitecture during pre and post-implantation periods of rats treated with aqueous extract of Moringa oleifera Lam. Acta Eur. Fertil. 18, 129-135.

Prakash, A. O., Pathak, S., Shukla, S., and Mathur, R. (1988). Pre and PostImplantation changes in the uterus of rats: response to Moringa Oleifera Lam. Extract. Anc. Sci. Life. 8, 49-54.

Rahman, M. M., Rahman, M. M., Akhter, S., Jamal, M. A., Pandeya, D. R., Haque, M. A., et al. (2010). Control of coliform bacteria detected from diarrhea associated patients by extracts of Moringa oleifera. Nepal Med. Coll. J. 12, 12-19.

Rajan, T. S., De Nicola, G. R., Iori, R., Rollin, P., Bramanti, P., and Mazzon, E. (2016). Anticancer activity of glucomoringin isothiocyanate in human malignant astrocytoma cells. Fitoterapia 110, 1-7. doi: 10.1016/j.fitote.2016.02.007

Randriamboavonjy, J. I., Loirand, G., Vaillant, N., Lauzier, B., Derbre, S., Michalet, S., et al. (2016). Cardiac protective effects of Moringa oleifera seeds in spontaneous hypertensive rats. Am. J. Hypertens. 29, 873-881. doi: 10.1093/ajh/hpw001

Rao, C. V., Hussain, T., Verma, A. R., Kumar, N., Vijaykumar, M., and Reddy, G. D. (2008). Evaluation of the analgesic and anti-inflammatory activity of Moringa concanensis tender fruits. Asian J. Tradit. Med. 3, 95-102.

Rashid, U., Anwar, F., Moser, B. R., and Knothe, G. (2008). Moringa oleifera oil: a possible source of biodiesel. Bioresour. Technol. 99, 8175-8179. doi: 10.1016/j.biortech.2008.03.066

Rathi, B. S., Bodhankar, S. L., and Baheti, A. M. (2006). Evaluation of aqueous leaves extract of Moringa oleifera Linn for wound healing in albino rats. Indian J. Exp. Biol. 44, 898-901. 
Rattanasena, P. (2012). Antioxidant and antibacterial activities of vegetables and fruits commonly consumed in Thailand. Pak. J. Biol. Sci. 15, 877-882. doi: $10.3923 /$ pjbs.2012.877.882

Ravichandiran, V., Suresh, B., Sathishkumar, M. N., Elango, K., and Srinivasan, R. (2007). Antifertility activity of hydro alcoholic extract of Moringa concanensis Nimmo: an ethnomedicines used by tribals of Nilgris region in Tamilnadu. Orient. Pharm. Exp. Med. 7, 114-120. doi: 10.3742/OPEM.2007.7.2.114

Saadabi, A. M., and Abu Zaid, I. E. (2011). An in vitro antimicrobial activity of Moringa oleifera L. seed extracts against different groups of microorganisms. Aust. J. Basic Appl. Sci. 5, 129-134.

Sadraei, H., Asghari, G., and Farahnaki, F. (2015). Assessment of hydroalcoholic extract of seeds and leaves of Moringa peregrina on ileum spasm. Res. Pharm. Sci. 10, 252-258.

Safaeian, L., Asghari, G., Javanmard, S. H., and Heidarinejad, A. (2015). The effect of hydroalcoholic extract from the leaves of Moringa peregrina (Forssk.) Fiori. on blood pressure and oxidative status in dexamethasone-induced hypertensive rats. Adv. Biomed. Res. 4, 1-11. doi: 10.4103/2277-9175.156681

Sahakitpichan, P., Mahidol, C., Disadee, W., Ruchirawat, S., and Kanchanapoom, T. (2011). Unusual glycosides of pyrrole alkaloid and $4^{\prime}$ hydroxyphenylethanamide from leaves of Moringa oleifera. Phytochemistry 72, 791-795. doi: 10.1016/j.phytochem.2011.02.021

Saini, R. K., Shetty, N. P., and Giridhar, P. (2014). Carotenoid content in vegetative and reproductive parts of commercially grown Moringa oleifera Lam. cultivars from India by LC-APCI-MS. Eur. Food Res. Technol. 238, 971-978. doi: $10.1007 /$ s00217-014-2174-3

Saini, R. K., Sivanesan, I., and Keum, Y. S. (2016). Phytochemicals of Moringa oleifera: a review of their nutritional, therapeutic and industrial significance. 3 Biotech. 6, 1-14. doi: 10.1007/s13205-016-0526-3

Sangkitikomol, W., Rocejanasaroj, A., and Tencomnao, T. (2014). Effect of Moringa oleifera on advanced glycation end-product formation and lipid metabolism gene expression in HepG2 cells. Genet. Mol. Res. 13, 723-735. doi: 10.4238/2014.January.29.3

Santhi, K., and Sengottuvel, R. (2016). The antioxidant activity of the methanolic leaf extract of Moringa concanensis Nimmo. Int. J. Adv. Interdiscipl. Res. $3,1-5$.

Sashidara, K. V., Rosaiah, J. N., Tyagi, E., Shukla, R., Raghubir, R., and Rajendran, S. M. (2009). Rare dipeptide and urea derivatives from roots of Moringa oleifera as potential antiinflammatory and antinociceptive agents. Eur. J. Med. Chem. 44, 432-436. doi: 10.1016/j.ejmech.2007.12.018

Sasikala, V., Rooban, B. N., Priya, S. G., Sahasranamam, V., and Abraham, A. (2010). Moringa oleifera prevents seleniteinduced cataractogenesis in rat pups. J. Ocul. Pharmacol. Ther. 26, 441-447. doi: 10.1089/jop.2010.0049

Satish, A., Sairam, S., Ahmed, F., and Urooj, A. (2012). Moringa oleifera Lam.: protease activity against blood coagulation cascade. Pharmacognosy Res. 4, 44-49. doi: 10.4103/0974-8490.91034

Seifu, E. (2014). Actual and potential applications of Moringa stenopetala, underutilized indigenous vegetable of Southern Ethiopia: a review. Int. J. Agric. Food Res. 3, 8-19.

Sethi, N., Nath, D., Shukla, S. C., and Dyal, R. (1988). Abortifacient activity of a medicinal plant "Moringa Oleifera" in rats. Anc. Sci. Life. 7, 172-174.

Shailemo, D. H. P., Kwaambwa, H. M., Kandawa-Schulz, M., and Msagati, T. A. M. (2016). Antibacterial activity of Moringa ovalifolia and Moringa oleifera Methanol, N-hexane and water seeds and bark extracts against pathogens that are implicated in water borne diseases.Green Sustain. Chem. 6, 71-77. doi: 10.4236/gsc.2016.62006

Shanker, K., Gupta, M. M., Srivastava, S. K., Bawankule, D. U., Pal, A., and Khanuja, S. P. S. (2007). Determination of bioactive nitrile glycoside(s) in drumstick (Moringa oleifera) by reverse phase HPLC. Food Chem. 105, 376-382. doi: 10.1016/j.foodchem.2006.12.034

Shih, M. C., Chang, C. M., Kang, S. M., and Tsai, M. L. (2011). Effect of different parts (leaf, stem and stalk) and seasons (summer and winter) on the chemical compositions and antioxidant activity of Moringa oleifera. Int. J. Mol. Sci. 12, 6077-6088. doi: 10.3390/ijms12096077

Shukla, S., Mathur, R., and Prakash, A. O. (1988). Antifertility profile of the aqueous extract of Moringa oleifera roots. J. Ethnopharmacol. 22, 51-62. doi: 10.1016/0378-8741(88)90230-9

Singh, B. N., Singh, B. R., Singh, R. L., Prakash, D., Dhakarey, R., Upadhyay, G., et al. (2009). Oxidative DNA damage protective activity, antioxidant and antiquorum sensing potentials of Moringa oleifera. Food Chem. Toxicol. 47, 1109-1116. doi: 10.1016/j.fct.2009.01.034

Singh, M. K., Paul, J., De, T., and Chakraborti, T. (2015). Bioactivity guided fractionation of Moringa oleifera Lam. flower targeting Leishmania donovani. Indian J. Exp. Biol. 53, 747-752.

Sinha, M., Das, D. K., Bhattacharjee, S., Majumdar, S., and Dey, S. (2011). Leaf Extract of Moringa oleifera prevents ionizing radiation induced oxidative stress in mice. J. Med. Food. 14, 1167-1172. doi: 10.1089/jmf.2010.1506

Silver, J. (2017). Moringa Oleifera: The Future of Health. Village volunteers, 1-9.

Sivasankari, B., Anandharaj, M., and Gunasekaran, P. (2014). An ethnobotanical study of indigenous knowledge on medicinal plants used by the village peoples of Thoppampatti, Dindigul district, Tamilnadu, India. J. Ethnopharmacol. 153, 408-423. doi: 10.1016/j.jep.2014.02.040

Soltan, M. M., and Zaki, A. K. (2009). Antiviral screening of fortytwo Egyptian medicinal plants. J. Ethnopharmacol. 126, 102-107. doi: 10.1016/j.jep.2009.08.001

Sreelatha, S., and Padma, P. R. (2011). Modulatory effects of Moringa oleifera extracts against hydrogen peroxide-induced cytotoxicity and oxidative damage. Hum. Exp. Toxicol. 30, 1359-1368. doi: 10.1177/0960327110391385

Tan, W. S., Arulselvan, P., Karthivashan, G., and Fakurazi, S. (2015). Moringa oleifera flower extract suppresses the activation of inflammatory mediators in lipopolysaccharide-stimulated RAW 264.7 macrophages via NF-кB pathway. Mediators Inflamm. 2015, 1-11. doi: 10.1155/2015/720171

Teixera, E. M., Carvalho, M. R., Neves, V. A., Silva, M. A., and ArantesPereira, L. (2014). Chemical characteristics and fractionation of proteins from Moringa oleifera Lam. leaves. Food Chem. 147, 51-54. doi: 10.1016/j.foodchem.2013.09.135

Teklehaymanot, T., and Giday, M. (2010). Quantitative ethnobotany of medicinal plants used by Kara and Kwego semi-pastoralist people in lower Omo River Valley, Debub Omo Zone, Southern Nations, Nationalities and Peoples Regional State, Ethiopia. J. Ethnopharmacol. 130, 76-84. doi: 10.1016/j.jep.2010.04.013

Tesemma, M., Adane, L., Tariku, Y., Muleta, D., and Demise, S. (2013). Isolation of compounds from acetone extract of root wood of Moringa stenopetala and evaluation of their antibacterial activities. Res. J. Med. Plant. 7, 32-47. doi: 10.3923/rjmp.2013.32.47

Tiloke, C., Phulukdaree, A., and Chuturgoon, A. A. (2013). The antiproliferative effect of Moringa oleifera crude aqueous leaf extract on cancerous human alveolar epithelial cells. BMC Complement Altern Med. 13:226. doi: 10.1186/1472-6882-13-226

Toma, A., Makonnen, E., Mekonnen, Y., Debella, A., and Adisakwattana, S. (2014) Intestinal alpha glucosidase and some pancreatic enzymes inhibitory effect of hydroalcoholic extract of Moringa stenopetala leaves. BMC Complement Altern Med 14:180. doi: 10.1186/1472-6882-14-180

Torondel, B., Opare, D., Brandberg, B., Cobb, E., and Cairncross, S. (2014). Efficacy of Moringa oleifera leaf powder as a hand-washing product: a crossover controlled study among healthy volunteers. BMC Complement Altern. Med. 14:57. doi: 10.1186/1472-6882-14-57

Tumer, T. B., Rojas-Silva, P., Poulev, A., Raskin, I., and Waterman, C. (2015). Direct and indirect antioxidant activity of polyphenol- and isothiocyanateenriched fractions from Moringa oleifera. J. Agric. Food Chem. 63, 1505-1513. doi: $10.1021 /$ jf $505014 \mathrm{n}$

Tuorkey, M. J. (2016). Effects of Moringa oleifera aquoeus leaf extract in alloxan induced diabetic mice. Interv. Med. Appl. Sci. 8, 109-117. doi: 10.1556/1646.8.2016.3.7

Uma, N. J., Fakurazi, S., and Hairuszah, I. (2010). Moringa oleifera enhances liver antioxidant status via elevation of antioxidant enzymes activity and counteracts paracetamol-induced hepatotoxicity. Malays. J. Nutr. 16, 293-307.

Verma, A. R., Vijayakumar, M., Mathela, C. S., and Rao, C. V. (2009). In vitro and in vivo antioxidant properties of different fractions of Moringa oleifera leaves. Food Chem. Toxicol. 47, 2196-2201. doi: 10.1016/j.fct.2009.06.005

Vijayakumar, S., and Sumathi, A. (2016). Preliminary phytochemical and GCMS analysis of bioactive compounds from Moringa concanensis Nimmo leaves family: Moringaceae. Int. J. Recent Adv. Multidiscipl. Res. 3, 1257-1259.

Vijayarajan, M., and Pandian, M. R. (2016). Cytotoxicity of methanol and acetone root bark extracts of Moringa concanensis against A549, Hep-G2 and HT-29 cell lines. J. Acad. Ind. Res. 5, 45-49. 
Vongsak, B., Gritsanapan, W., Wongkrajang, Y., and Jantan, I. (2013). In vitro inhibitory effects of Moringa oleifera leaf extract and its major components on chemiluminescence and chemotactic activity of phagocytes. Nat. Prod. Commun. 8, 1559-1561.

Vongsak, B., Mangmool, S., and Gritsanapan, W. (2015). Antioxidant activity and induction of mRNA expressions of antioxidant enzymes in HEK-293 cells of Moringa oleifera Leaf extract. Planta Med. 81, 1084-1089. doi: 10.1055/s-0035-1546168

Vongsak, B., Sithisarn, P., and Gritsanapan, W. (2014). Simultaneous HPLC quantitative analysis of active compounds in leaves of Moringa oleifera Lam. J. Chromatogr. Sci. 52, 641-645. doi: 10.1093/chromsci/ bmt093

Waiyaput, W., Payungporn, S., Issara-Amphorn, J., and Panjaworayan, T. N. (2012). Inhibitory effects of crude extracts from some edible Thai plants against replication of hepatitis B virus and human liver cancer cells. BMC Complement Altern Med. 12:246. doi: 10.1186/1472-6882-12-246

Walter, A., Samuel, W., Peter, A., and Jospeh, O. (2011). Antibacterial activity of Moringa oleifera and Moringa stenopetala methanol and n-hexane seed extracts on bacteria implicated in water borne diseases. Afr. J. Microbiol. Res. 5, 153-157. doi: 10.5897/AJMR10.457

Wang, Y., Gao, Y., Ding, H., Liu, S., Han, X., Gui, J., et al. (2017). Subcritical ethanol extraction of flavanoids from Moringa oleifera leaf and evaluation of antioxidant activity. Food Chem. 218, 152-158. doi: 10.1016/j.foodchem.2016.09.058

Waterman, C., Cheng, D. M., Rojas-Silva, P., Poulev, A., Dreifus, J., Lila, M. A., et al. (2014). Stable, water extractable isothiocyanates from Moringa oleifera leaves attenuate inflammation in vitro. Phytochemistry 103, 114-122. doi: 10.1016/j.phytochem.2014.03.028
Waterman, C., Rojas-Silva, P., Tumer, T. B., Kuhn, P., Richard, A. J., Wicks, S., et al. (2015). Isothiocyanate-rich Moringa oleifera extract reduces weigh gain, insulin resistance and hepatic gluconeogenesis in mice. Mol. Nutr. Food Res. 59, 1013-1024. doi: 10.1002/mnfr.201400679

Yabesh, J. E., Prabhu, S., and Vijayakumar, S. (2014). An ethnobotanical study of medicinal plants used by traditional healers in silent valley of Kerala, India. $J$. Ethnopharmacol. 154, 774-789. doi: 10.1016/j.jep.2014.05.004

Younus, I., Siddiq, A., Ishaq, H., Anwer, L., Badar, S., and Ashraf, M. (2016). Evaluation of antiviral activity of plant extracts against foot and mouth disease virus in vitro. Pak. J. Pharm. Sci. 29, 1263-1268.

Zaffer, M., Ahmad, S., Sharma, R., Mahajan, S., Gupta, A., and Agnihotri, R. K. (2014). Antibacterial activity of bark extracts of Moringa oleifera Lam. against some selected bacteria. Pak. J. Pharm. Sci. 27, 1857-1862.

Zaghloul, M. S., Hamrick, J. L., and Moustafa, A. A. (2012). Conservation genetics of Sinai's remnant populations of Moringa peregrina, an economically valuable medicinal plant. Conserv. Genet. 13, 9-19. doi: 10.1007/s10592-011-0260-7

Conflict of Interest Statement: The authors declare that the research was conducted in the absence of any commercial or financial relationships that could be construed as a potential conflict of interest.

Copyright (c) 2018 Abd Rani, Husain and Kumolosasi. This is an open-access article distributed under the terms of the Creative Commons Attribution License (CC BY). The use, distribution or reproduction in other forums is permitted, provided the original author(s) and the copyright owner are credited and that the original publication in this journal is cited, in accordance with accepted academic practice. No use, distribution or reproduction is permitted which does not comply with these terms. 